Article

\title{
Effects of Different Land Use Types and Soil Depths on Soil Mineral Elements, Soil Enzyme Activity, and Fungal Community in Karst Area of Southwest China
}

\author{
Jiyi Gong ${ }^{1,+}$, Wenpeng Hou ${ }^{2,3,+}$, Jie Liu ${ }^{1}$, Kamran Malik ${ }^{3} \mathbb{D}$, Xin Kong ${ }^{1}$, Li Wang ${ }^{1}$, Xianlei Chen ${ }^{1}$, Ming Tang ${ }^{1} \mathbb{D}$, \\ Ruiqing Zhu ${ }^{4}$, Chen Cheng ${ }^{2,3} \mathbb{D}$, Yinglong Liu ${ }^{2,3} \mathbb{D}$, Jianfeng Wang ${ }^{2,3,5,6, *(\mathbb{D})}$ and Yin Yi ${ }^{1, *}$
}

\section{check for} updates

Citation: Gong, J.; Hou, W.; Liu, J.; Malik, K.; Kong, X.; Wang, L.; Chen, X.; Tang, M.; Zhu, R.; Cheng, C.; et al. Effects of Different Land Use Types and Soil Depths on Soil Mineral Elements, Soil Enzyme Activity, and Fungal Community in Karst Area of Southwest China. Int. J. Environ. Res. Public Health 2022, 19, 3120. https:/ / doi.org/10.3390/ijerph19053120

Academic Editor: Giulia Maisto

Received: 2 February 2022

Accepted: 1 March 2022

Published: 7 March 2022

Publisher's Note: MDPI stays neutral with regard to jurisdictional claims in published maps and institutional affiliations.

Copyright: (C) 2022 by the authors. Licensee MDPI, Basel, Switzerland. This article is an open access article distributed under the terms and conditions of the Creative Commons Attribution (CC BY) license (https:// creativecommons.org/licenses/by/ $4.0 /)$.
1 Key Laboratory of National Forestry and Grassland Administration on Biodiversity Conservation in Karst Mountainous Areas of Southwestern China, Guizhou Normal University, Guiyang 550025, China; 201307048@gznu.edu.cn (J.G.); lanzhoudaxue2022@163.com (J.L.); kongxin1232022@163.com (X.K.); gznu_wangli0521@163.com (L.W.); chenxianlei0321@163.com (X.C.); mingtang@gznu.edu.cn (M.T.)

2 State Key Laboratory of Grassland Agro-Ecosystems, Center for Grassland Microbiome, Lanzhou University, Lanzhou 730000, China; houwp19@lzu.edu.cn (W.H.); chengch20@lzu.edu.cn (C.C.); liuy12020@1zu.edu.cn (Y.L.)

3 College of Pastoral Agriculture Science and Technology, Lanzhou University, Lanzhou 730000, China; malik@lzu.edu.cn

4 Qinghai Provincial Key Laboratory of Medicinal Plant and Animal Resources of Qinghai-Tibet Plateau, Academy of Plateau Science and Sustainability, School of Life Sciences, Qinghai Normal University, Xining 810008, China; zrq15002679150@163.com

5 Collaborative Innovation Center for Western Ecological Safety, Lanzhou University, Lanzhou 730000, China

6 State Key Laboratory of Plateau Ecology and Agriculture, Qinghai University, Xining 810016, China

* Correspondence: wangjf12@lzu.edu.cn (J.W.); yiyin@gznu.edu.cn (Y.Y.)

+ These authors contributed equally to this work.

\begin{abstract}
The current research was aimed to study the effects of different land use types (LUT) and soil depth (SD) on soil enzyme activity, metal content, and soil fungi in the karst area. Soil samples with depths of $0-20 \mathrm{~cm}$ and $20-40 \mathrm{~cm}$ were collected from different land types, including grassland, forest, Zanthoxylum planispinum land, Hylocereus spp. land and Zea mays land. The metal content and enzyme activity of the samples were determined, and the soil fungi were sequenced. The results showed that LUT had a significant effect on the contents of soil $\mathrm{K}, \mathrm{Mg}, \mathrm{Fe}, \mathrm{Cu}$ and $\mathrm{Cr}$; LUT and SD significantly affected the activities of invertase, urease, alkaline phosphatase and catalase. In addition, Shannon and Chao1 index of soil fungal community was affected by different land use types and soil depths. Ascomycota, Basidiomycota and Mortierellomycota were the dominant phyla at 0-20 cm and $20-40 \mathrm{~cm}$ soil depths in five different land types. Land use led to significant changes in soil fungal structure, while soil depth had no significant effect on soil fungal structure, probably because the small-scale environmental changes in karst areas were not the dominant factor in changing the structure of fungal communities. Additionally, metal element content and enzyme activity were related to different soil fungal communities. In conclusion, soil mineral elements content, enzyme activity, and soil fungal community in the karst area were strongly affected by land use types and soil depths. This study provides a theoretical basis for rational land use and ecological restoration in karst areas.
\end{abstract}

Keywords: karst areas; soil depth; land use types; soil metal elements; soil enzyme activity; soil fungal community and diversity

\section{Introduction}

Karst landform is a variety of peculiar landforms formed on the surface and underground under the continuous dissolution of a large number of soluble rocks by flowing water. Karst area accounts for about $12 \%$ of the world's land area [1]. Due to the unique 
geographical conditions, the southwest karst region centered on Guizhou Province in China has the largest continuous coverage area of about a 5.1 million $\mathrm{km}^{2}$ in the world. It is also the most complete development type and typical karst ecosystem in the world [2]. However, the karst ecosystem is highly heterogeneous and fragile, and can cause rocky desertification [3]. Here, arable land is limited by rocks, and soil functions and ecosystem services are negatively affected by poorly managed land use patterns [4].

Land use, as a comprehensive reflection of human behaviors, is closely related to plant communities, soil nutrients and soil enzyme activities, resulting in differences in soil microbial characteristics [5]. Studies have confirmed that different land use patterns showed significant effects on soil nutrients in karst areas of Southwest China [6]. There were differences in community structure/diversity of soil fungi in different vegetation succession stages in the karst area and the soil bacterial community had complex responses to tillage patterns [7]. Both soil enzyme activity and microbial community structure depend on land use patterns. Therefore, in this case, land use conversion in the karst area has become a major issue. Additionally, different depths of the soil layer influence soil microorganisms, vegetation types, and litter quality, which leads to the difference in microbial community structure. Few studies claimed that microbial respiration activity, biomass and diversity were decreased with soil depth and the number of bacteria in the topsoil layers of three different land types was 2-20 times more than the lower layer in the karst area compared to the non-karst [8,9]. Hence, the change of soil nutrients from top to bottom in the karst area is very clear. In recent years, local farmers have been encouraged to grow different cash crops, to improve the ecological environment of the karst area. Therefore, exploring the effects of different land use patterns and soil layers is helpful for ecological restoration in this fragile ecological area.

Soil enzymes have a high catalytic capacity and take part in organic matter decomposition and cycling of nutrient in ecosystem [10]. Soil nutrients, microorganisms, vegetation types and management measures affect soil enzyme activities in different degrees [11-13]. More importantly, soil enzyme activity can represent the rate of nutrient uptake by microorganisms and plants. Enzymes are sensitive to reflect the early changes of soil quality caused by soil management [14]. Soil invertase plays a vital role in C decomposition, transformation, and soil bio-respiration [15]. Urease converts organic $\mathrm{N}$ to available $\mathrm{N}$ by hydrolyzing urea [16]. In addition, alkaline phosphatase plays an important role in organic phosphorus (P) mineralization and plant $\mathrm{P}$ nutrition, especially in calcareous soil with limited P [17]. Microbial activity is a key indicator to detect soil quality and to control land degradation which fully shows that soil microorganism is still an important research direction, especially in karst areas. However, the majority of the studies focused on the soil bacterial community in the karst area, such as the response of soil bacterial community structure to different disturbances [18] and the correlation between vegetation succession and bacterial metabolic diversity [19]. Fungi are the basic components of the soil microbial community, and it is necessary to investigate the relationship between soil fungal community and land use types.

Heavy metals are widespread on the earth's surface which are persistent, stable, and difficult to degrade [20]. In recent years, due to unreasonable exploitation of mineral resources, improper disposal of hazardous wastes, and the extreme vulnerability of groundwater systems, heavy metals in karst areas have been seriously diffused, posing a serious threat to the biological community [21,22]. Studies have shown that land use can directly or indirectly affect the content of heavy metals by changing soil properties [23,24]. Soil enzymes produced by microbial metabolism can be used as monitoring factors for heavy metals. Soil mineral elements are also important indicators to determine soil fertility and the healthy growth of plants. For instance, potassium and sodium are closely related to the soil microbial community in the karst ecosystem [25].

Land use conversion is a part of China's policy of "Grain for Green Project"; however, little is known about the effects of different land use patterns and soil depths on mineral elements content, enzyme activities and fungal communities in karst areas, Southwest 
China. In the current study, the contents of soil mineral elements, soil enzyme activities and fungal communities in five land use types and two soil depths in Guizhou Province of China were investigated to provide a theoretical basis for soil management and ecological restoration in karst areas.

\section{Materials and Methods}

\subsection{Study Area and Soil Sampling}

Huajiang town is located in Guanling Buyi and Miao Autonomous county, Anshun city, Guizhou province, southwest China with an area of $294.9 \mathrm{~km}^{2}$ (Altitude $1439 \mathrm{~m}$, $\left.105^{\circ} 34^{\prime} \mathrm{E}, 25^{\circ} 43^{\prime} \mathrm{N}\right)$, which is a typical karst landform. The study site is dominated by the humid subtropical monsoon climate, and the annual mean temperature and rainfall are $17{ }^{\circ} \mathrm{C}$ and $1200 \mathrm{~mm}$ per year, respectively, while the frost-free period is about 288 days. In November 2019, we selected five land use types, including: grassland (the main species are Themeda japonica and is located in $105^{\circ} 28^{\prime} 42^{\prime \prime}, 25^{\circ} 43^{\prime} 48^{\prime \prime}$, altitude $851 \mathrm{~m}$ ), secondary forest (the main species are Liquidambar formosana and is located in $105^{\circ} 28^{\prime} 46^{\prime \prime}, 25^{\circ} 43^{\prime} 48^{\prime \prime}$, altitude $798 \mathrm{~m}$ ); pepper field (the main cultured species are Zanthoxylum planispinum and is located in $105^{\circ} 39^{\prime} 58^{\prime \prime}, 25^{\circ} 40^{\prime} 07^{\prime \prime}$, altitude $517 \mathrm{~m}$ ), dragon fruit field (the main cultured species is Hylocereus spp. and locate in $105^{\circ} 39^{\prime} 41^{\prime \prime}, 25^{\circ} 40^{\prime} 33^{\prime \prime}$, altitude $598 \mathrm{~m}$ ) and maize field (the main cultured species are Zea mays and is located in $105^{\circ} 39^{\prime} 42^{\prime \prime}, 25^{\circ} 40^{\prime} 33^{\prime \prime}$, altitude $798 \mathrm{~m}$ ). There were 5 sampling points for each land use type, the area of each sampling point is $4 \mathrm{~m} \times 4 \mathrm{~m}$, and the distance between each sampling point was $5 \mathrm{~m}$. After removing 1-2 cm of topsoil, soil samples were collected at depths of 0-20 cm and 20-40 cm. Each soil sample was mixed from four subplots $(1 \mathrm{~m} \times 1 \mathrm{~m}$ range) at $0-20 \mathrm{~cm}$ and $20-40 \mathrm{~cm}$ soil depths, respectively, and collected in dry, clean, sterile polyethylene bags. Next, all soil samples were passed through a $2 \mathrm{~mm}$ sieve to remove visible roots and stones. A portion of each soil sample was transferred in the $50 \mathrm{~mL}$ sterile centrifuge tube and placed in a liquid nitrogen tank. The samples were transported to the laboratory, and the sterile centrifuge tube was immediately stored in an ultra-low temperature refrigerator at $-80{ }^{\circ} \mathrm{C}$ for subsequent soil enzyme activity measurement and soil DNA extraction. The other portion of the soil samples were kept for natural drying to determine the content of soil mineral elements.

\subsection{Soil Mineral Elements Content Assay}

The contents of soil mineral elements include potassium $\left(\mathrm{K}^{+}\right)$, calcium $\left(\mathrm{Ca}^{2+}\right)$, sodium $\left(\mathrm{Na}^{+}\right)$, magnesium $\left(\mathrm{Mg}^{2+}\right)$, iron $\left(\mathrm{Fe}^{3+}\right)$, copper $\left(\mathrm{Cu}^{2+}\right)$, zinc $\left(\mathrm{Zn}^{2+}\right)$, cadmium $\left(\mathrm{Cd}^{2+}\right)$, chromium $\left(\mathrm{Cr}^{2+}\right)$ and lead $\left(\mathrm{Pb}^{2+}\right)$ were determined by atomic absorption spectroscopy method after digestion according to the method described by Li et al. [26] The contents of soil mineral elements were measured by TRACE AI1200 atomic absorption spectrometer (Canada Aurora, Vancouver, BC, Canada).

\subsection{DNA Extraction and Illumina Sequencing}

Soil DNA (300 mg) was extracted using the power soil DNA extraction and separation kit according to the protocol of the manufacturer (MoBio, Carlsbad, CA, USA). The ITS1 region of the fungal rRNA gene was amplified by PCR as described by Zhong et al. [27]. The primers were ITS1 (5'-CTTGGTCATTTAGAGGAAGTAA-3 $\left.{ }^{\prime}\right)$ and ITS2 (5'-GCTGCGTTCTTCATCGATGC-3'). The PCR procedure consisted of 27 cycles at $94{ }^{\circ} \mathrm{C}$ for $2 \mathrm{~min}, 94^{\circ} \mathrm{C}$ for $30 \mathrm{~s}, 55^{\circ} \mathrm{C}$ for $30 \mathrm{~s}$, and $72{ }^{\circ} \mathrm{C}$ for $60 \mathrm{~s}$, and $72{ }^{\circ} \mathrm{C}$ for $10 \mathrm{~min}$. PCR products were sent to Genesky Biotechnologies Inc., Shanghai, 201,315 (China) for sequencing with an Illumina $2 \times 250 \mathrm{bp}$ platform.

\subsection{Sequencing Data Processing and Analysis}

The original sequence was filtered using the method described by Caporaso et al. [28] to eliminate the low-quality sequence, and then the ITS2 region was extracted by the same method used by Bengtsson-Palme et al. [29]. In the subsequent examination of potential chimeras, the uchime command in mothur version 1.31.2 [30] was used and compared with 
entries in the DNA based fungal species unified system related to the classification (unite) database [31]. Finally, after dereplicating and discarding all monomers, the non-chimeric sequences were aggregated into the operational taxonomic units (OTUs), and the OTUs were clustered based on the UPARSE pipeline using USEARCH version 8.0 (the similarity of OTU is $97 \%$ [32].

\subsection{Soil Enzymes Assay}

The activities of soil invertase (Inv), urease (Ure), and alkaline phosphatase (Alp)was measured by 3,5-Dinitrosalicylic acid colorimetry, sodium phenol-sodium hypochlorite and disodium diphenyl phosphate colorimetry, respectively according to description of Hou et al. [33]. The activity of soil catalase (Cat) was determined by Potassium permanganate titration according to Chao et al. [34].

\subsection{Statistical Analyses}

The data were analyzed using SPSS software 17.0 (IBM Inc., Armonk, NY, USA). The effects of land use type (LUT) and soil depth (SD) on the soil fungal alpha diversity (Chao1 and Shannon indices), soil mineral elements content and soil enzyme activity were analyzed by two-way ANOVA. Statistical significance was defined as $p=0.05$ confidence level, and the mean was evaluated by the standard error. The Chao1, Shannon, the heatmap, PCoA, redundancy analysis (RDA), Variance Partitioning Analysis (VPA) and Spearman's rank correlation analysis were carried out in $\mathrm{R}$ (version 3.2.2). The Linear discriminant analysis (LDA) coupled with effect size measurement (LEfSe) analysis was performed using the OmicStudio tools at https:/ / www.omicstudio.cn/tool (accessed on 27 December 2021).

\section{Results}

\subsection{Differences in Content of Soil $\mathrm{K}, \mathrm{Na}, \mathrm{Ca}, \mathrm{Mg}$ and Fe in Different Land Use Types and} Soil Depths

Table S1 presented data on soil $\mathrm{K}, \mathrm{Na}, \mathrm{Ca}, \mathrm{Mg}$ and Fe contents as influenced by land use types (LUT) and soil depth (SD). Our results showed that LUT have significant effects on soil K $(p<0.001)$, Na $(p=0.029)$, Ca $(p=0.01), \mathrm{Mg}(p<0.001)$ and $\mathrm{Fe}(p<0.001)$ contents. However, SD had no remarkable role in the content of all soil mineral elements. Additionally, the LUT $\times$ SD interaction only had a clear effect on Ca $(p<0.001)$ and $\mathrm{Mg}$ contents $(p<0.001)$ (Table S1). Further, we found that there was no significant difference in the $\mathrm{K}, \mathrm{Na}$, and $\mathrm{Mg}$ content between $0-20 \mathrm{~cm}$ and $20-40 \mathrm{~cm}$ soil layers under the five different land use types (Figure $1 \mathrm{~b}, \mathrm{c}, \mathrm{e}$ ). The soil Ca content at $0-20 \mathrm{~cm}$ depths in grassland and Zea mays was 2.3-fold higher and 1.4-fold lower than that at 20-40 cm depth, respectively (Figure 1d). Interestingly, the Fe content was significantly 1.6 times higher only in the 0-20 cm Zea mays soil compared to the $20-40 \mathrm{~cm}$ soil layer (Figure 1f). Different land use types also have different effects on soil mineral elements content. Significant differences in soil $\mathrm{K}, \mathrm{Mg}$, and Fe contents were found between land use types at both soil depths; however, land use type played no clear role on Na content in different soil layers (Figure 1). The highest levels of $\mathrm{K}$ were found in Zanthoxylum planispinum soils, while $\mathrm{Mg}$ and Fe contents were highest in grassland soils at both soil depths. Meanwhile the contents of $\mathrm{K}$ in grassland soil and Fe in Zanthoxylum planispinum soil were the lowest, (Figure 1b,e,f). Whereas, at the deep soil layer $(20-40 \mathrm{~cm})$, the Ca content was highest in the grassland soil and lowest in the Zea mays soil (Figure 1d). 
a

1: $0-20 \mathrm{~cm}$ soil depth

2: $20-40 \mathrm{~cm}$ soil depth

g: grass land

f: secondary forest land

z: Zanthoxylum planispinum land

h: Hylocereus spp. land

zm: Zea mays land
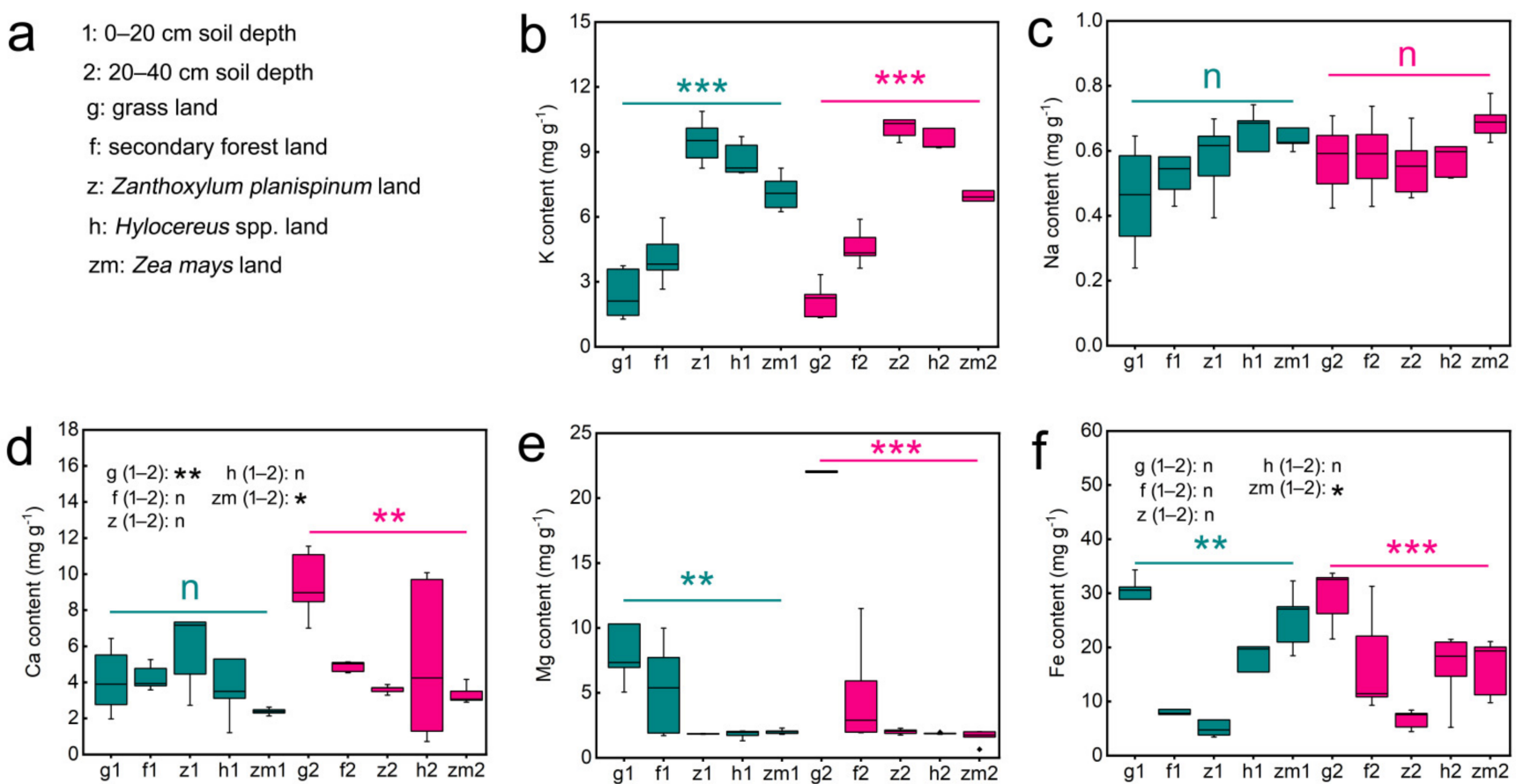

Figure 1. Effect of the different land use types on content of soil $\mathrm{K}, \mathrm{Na}, \mathrm{Ca}, \mathrm{Mg}$ Fe in 0-20 $\mathrm{cm}$ and 20-40 cm soil depth. (a) the description of abbreviations, (b) K content, (c) Na content, (d) Ca content, (e) $\mathrm{Mg}$ content, (f) Fe content. ** and ${ }^{* *}$ above green line and purple line indicate there are significant difference at $p<0.05, p<0.01$ and $p<0.001$ level between the five different land use types in $0-20 \mathrm{~cm}$ and $20-40 \mathrm{~cm}$ soil depths, respectively; $\mathrm{n}$ indicates that there is no statistically significantly different among the five different land use types. ${ }^{*}$ and ${ }^{* *}$ after $\mathrm{g} / \mathrm{f} / \mathrm{z} / \mathrm{h} / \mathrm{zm}(1-2)$ indicate significant difference at $p<0.05$ and $p<0.01$ level between $0-20 \mathrm{~cm}$ and $20-40 \mathrm{~cm}$ depths in the five different land use types, respectively, $\mathrm{n}$ indicates not statistically significantly different between $0-20 \mathrm{~cm}$ and $20-40 \mathrm{~cm}$ soil depths in the five different land use types, respectively.

\subsection{Differences in Content of soil $\mathrm{Cr}, \mathrm{Ni}, \mathrm{Cu}, \mathrm{Zn}, \mathrm{Cd}$ and $\mathrm{Pb}$ in Different Land Use Types and Soil Depths}

As shown in Table S2, soil $\mathrm{Cr}(p=0.033), \mathrm{Cu}(p<0.001), \mathrm{Zn}(p=0.011)$ and $\mathrm{Cd}(p<0.001)$ contents were obviously influenced by LUT. However, soil heavy metal levels were not significant to SD. Interestingly, LUT $\times$ SD interaction only affected soil Cu content $(p=0.026)$ (Table S2). Subsequent studies have shown that in the five different land use types, there was no significant difference in heavy metal content between different layers (Figure 2). However, we found that all heavy metal contents in deep soil layers were significantly affected by land use types. The highest content of $\mathrm{Cr}, \mathrm{Ni}$, and $\mathrm{Pb}$ existed in secondary forest soil and the lowest existed in Zea mays soil (Figure 2a,b,f). The contents of $\mathrm{Cu}, \mathrm{Zn}$ and $\mathrm{Cd}$ in grassland soil were significantly lower than the other land use types (Figure 2c-e). Moreover, soil $\mathrm{Cu}$ and $\mathrm{Cd}$ contents in Zanthoxylum planispinum and $\mathrm{Zn}$ content in the forest were the highest (Figure 2c-e). It should be noted that in the topsoil $(0-20 \mathrm{~cm})$, different land use types only affected the contents of $\mathrm{Cu}$ and $\mathrm{Cd}$, and the contents of $\mathrm{Cu}$ and $\mathrm{Cd}$ in Hylocereus spp. soil were significantly higher than those in other land types (Figure 2c,e). 

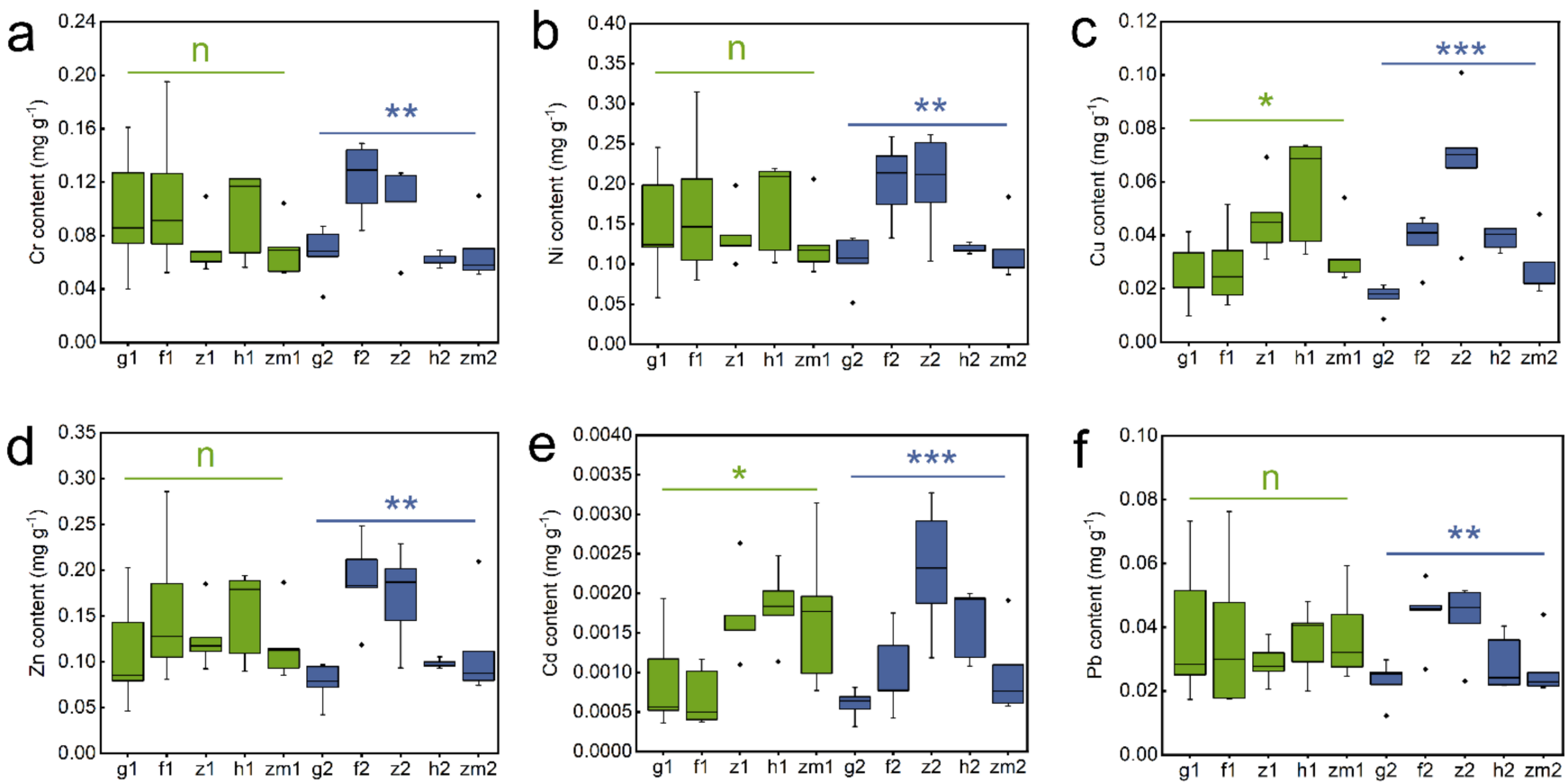

Figure 2. Effect of the different land use types on contents of $\mathrm{Cr}, \mathrm{Ni}, \mathrm{Cu}, \mathrm{Zn}, \mathrm{Cd}, \mathrm{Pb}$ in $0-20 \mathrm{~cm}$ and 20-40 cm soil depth. (a) Cr content, (b) Ni content, (c) Cu content, (d) Zn content, (e) Cd content, (f) $\mathrm{Pb}$ content. ${ }^{*}, * *$ and ${ }^{* *}$ above green line and blue line indicate there are significant difference at $p<0.05, p<0.01$ and $p<0.001$ level between the five different land use types in 0-20 $\mathrm{cm}$ and $20-40 \mathrm{~cm}$ soil depths, respectively; $\mathrm{n}$ indicates that there is no statistically significantly different among the five different land use types.

\subsection{Differences in Soil Enzyme Activity in Different Land Use Types and Soil Depths}

Statistical evaluation of the effects of land use types on enzyme activity were statistically significant $(p<0.05)$ as shown in Table S3, which the role of soil depth was considered. LUT significantly affected the activity of Inv $(p<0.001)$, Ure $(p<0.001)$, Alp $(p<0.001)$. SD and LUT $\times$ SD interaction all had extremely significant influence on the activity of the four enzymes $(p<0.001)$ (Table S3). With the increase in soil depth, the enzyme activities of different land use types all showed a downward trend. In grass land, Zanthoxylum planispinum and Hylocereus spp. soil, Inv activity in $0-20 \mathrm{~cm}$ soil decreased by 1.5 times, increased by 1.7 times and 3.6 times compared with that in $20-40 \mathrm{~cm}$ soil depths, respectively (Figure 3a). The activity of Ure at soil depths of $0-20 \mathrm{~cm}$ in grassland, forest, and Zanthoxylum planispinum was 1.7, 4.3 and 12.9 times higher than that in $20-40 \mathrm{~cm}$ soil, respectively, but it was 5.7 times lower in 0-20 cm soil compared to $20-40 \mathrm{~cm}$ depths in Zea mays soil (Figure $3 b$ ). The Alp activity in $0-20 \mathrm{~cm}$ depth was increased by $2.2,1.7$ and 1.6 times compared to $20-40 \mathrm{~cm}$ depth in forest land, Hylocereus spp. and Zea mays soil, respectively (Figure 3c). Similarly, Cat activity in topsoil of Hylocereus spp. and Zea mays soil was significantly higher than that in deep soil layers, which was 1.9 and 1.8 times, respectively (Figure 3d). Further, we studied the response of soil enzyme activities to land use types at different depths. At the two soil depths, different land use types had significant effects on soil enzyme activity. The activity of Inv and Ure was highest at $0-20 \mathrm{~cm}$ depths of Zanthoxylum planispinum lowest in grass land. In $20-40 \mathrm{~cm}$ soil layer, Inv activity was the highest in forest, and the lowest was found in Hylocereus spp. soil(Figure 3a). Urease activity was the lowest in 0-20 cm layer of Zea mays soil. On the contrary, in $20-40 \mathrm{~cm}$ layer, its activity was the highest in Zea mays soil and the lowest in grass land (Figure 3b). In shallow soil, the activity of Alp was the highest in forest, and the lowest in Hylocereus spp. Interestingly, the lowest activity of Alp and catalase in deep soil all existed in Hylocereus spp. soil (Figure 3c,d). 

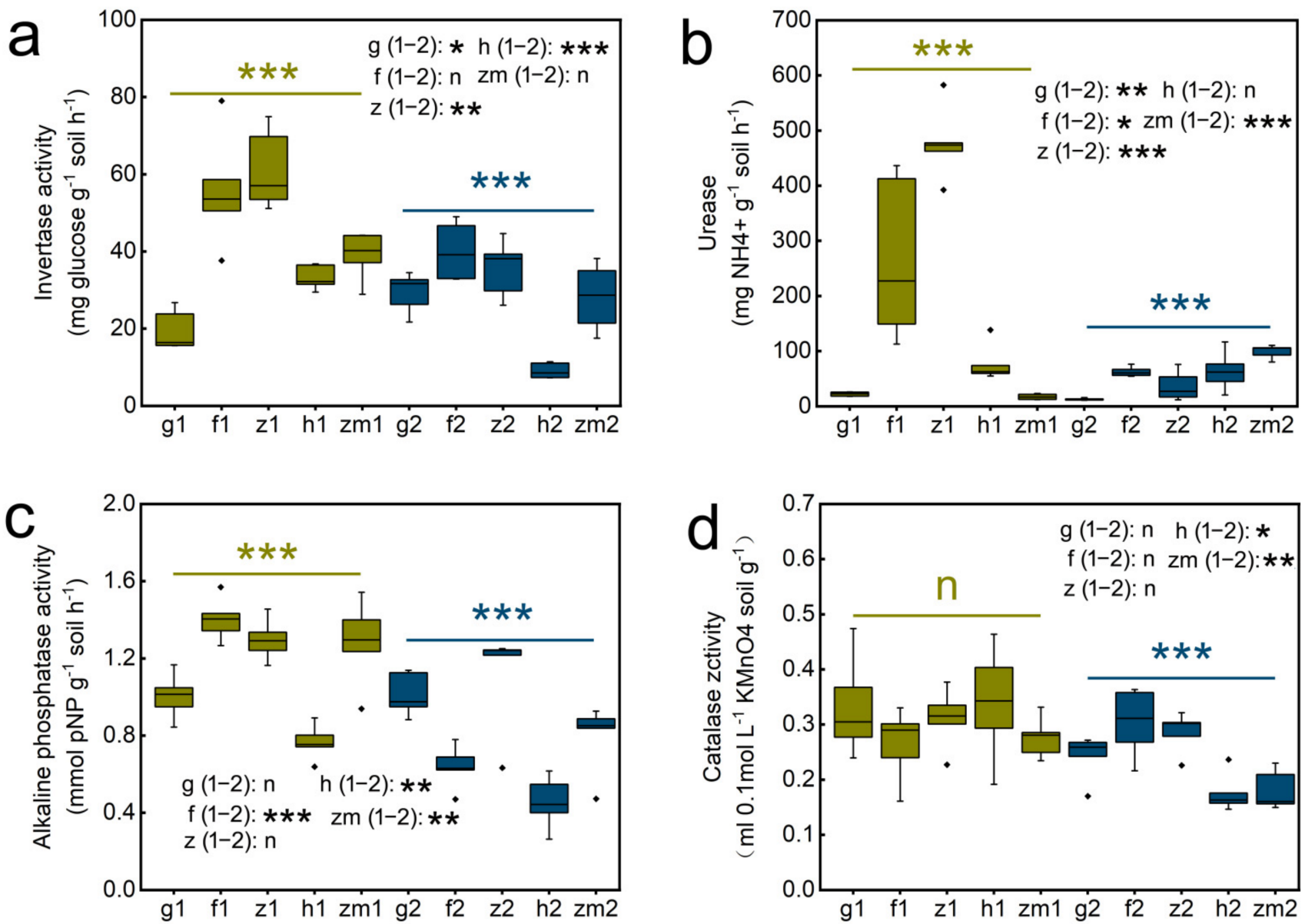

Figure 3. Effect of the different land use types on soil enzyme activity in 0-20 cm and $20-40 \mathrm{~cm}$ soil depth. (a) invertase (Inv) activity (b) urease (Ure) activity, (c) alkaline phosphatase (Alp) activity, (d) catalase (Cat) activity. ${ }^{* * *}$ above yellow line and blue line indicate there were significant difference at $p<0.001$ level between the five different land use types in 0-20 cm and 20-40 cm soil depths, respectively; $\mathrm{n}$ indicates that there is no statistically significantly different among the five different land use types. ${ }^{*}{ }^{* *}$ and ${ }^{* * *}$ after $\mathrm{g} / \mathrm{f} / \mathrm{z} / \mathrm{h} / \mathrm{zm}(1-2)$ indicate significant difference at $p<0.05, p<0.01$ and $p<0.001$ level between $0-20 \mathrm{~cm}$ and $20-40 \mathrm{~cm}$ depths at the five different land use types, respectively, $\mathrm{n}$ indicates not statistically significantly different between $0-20 \mathrm{~cm}$ and $20-40 \mathrm{~cm}$ soil depths at the five different land use types, respectively. The abbreviations are described in Figure 1a.

\subsection{The Richness and Diversity of Soil Fungal Community}

We found that LUT and SD had an obvious effect on the Shannon index $(p=0.018$; $p=0.004$, respectively, Table S4), but the Shannon index was not significantly affected by the interaction of LUT and SD. Similarly, LUT had a marked influence on the Chao 1 index $(p=0.028, p=0.03$, respectively, Table S4), and LUT $\times$ SD caused a significant influence on the Chao 1 ( $p=0.032$, Table S4). Our results also showed that Shannon and Chao 1 index were affected by different soil depth and land use types. In Zea mays, the Shannon and Chao 1 index in the topsoil layers are all significantly higher than that of the deep soil layers, and the Shannon and Chao 1 of topsoil layers in Zea mays land were 1.21 times and 1.42 times higher than those of deep soil layers, respectively (Figure 4a,b). However, the rest of the land use types did not change significantly with the change of soil depth. Additionally, Shannon at a soil depth of $0-20 \mathrm{~cm}$ in Zanthoxylum planispinum land was the highest $(4.87 \pm 0.15)$ and was the lowest in Hylocereus spp. land (3.86 \pm 0.15$)$ (Figure $4 \mathrm{a})$. The same result was shown in the Chao 1 . Chao 1 at $0-20 \mathrm{~cm}$ depth in Zanthoxylum 
planispinum land was the highest $(579.20 \pm 22.39)$ and Hylocereus spp. land was the lowest $(385.00 \pm 29.85)$ (Figure $4 b)$.
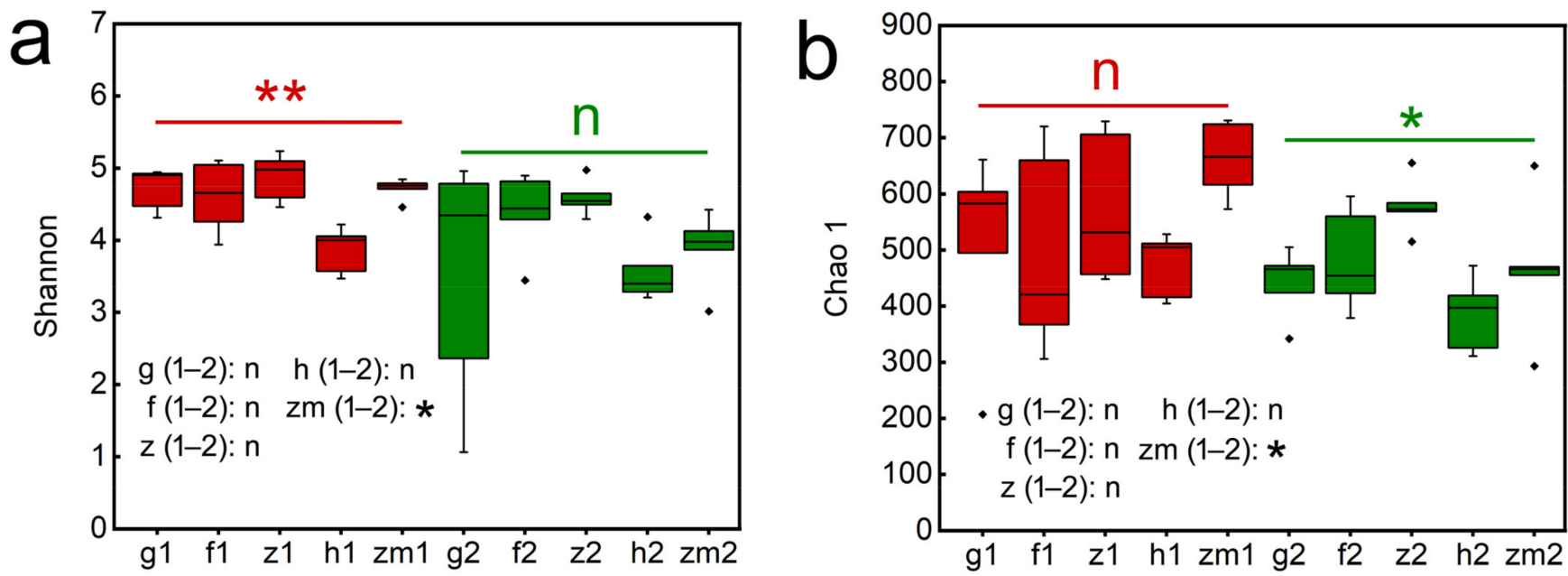

Figure 4. Effect of the different land use types on fungal alpha diversity, (a) Chao1, (b) Shanon in 0-20 cm and 20-40 cm soil depth. * and ${ }^{* *}$ above red line and green line indicate there are significant difference at $p<0.05$ and $p<0.01$ level between the five different land use types in $0-20 \mathrm{~cm}$ and 20-40 cm soil depths, respectively; $\mathrm{n}$ indicates that there is no statistically significantly different among the five different land use types. ${ }^{*}$ after $\mathrm{g} / \mathrm{f} / \mathrm{z} / \mathrm{h} / \mathrm{zm}(1-2)$ indicates significant difference at $p<0.05$ level between $0-20 \mathrm{~cm}$ and $20-40 \mathrm{~cm}$ depths at the five different land use types, respectively, $n$ indicates not statistically significantly different between $0-20 \mathrm{~cm}$ and $20-40 \mathrm{~cm}$ soil depths at the five different land use types, respectively. The abbreviations are described in Figure 1a.

\subsection{Relative Abundance of Soil Fungal Community}

Figure $5 \mathrm{a}, \mathrm{b}$ showed the relative abundances of major fungal phyla and genera in 0-20 $\mathrm{cm}$ and $20-40 \mathrm{~cm}$ soil depth in five different land use types, respectively. The Ascomycota, Basidiomycota, and Mortierellomycota were all the dominant phyla at $0-20 \mathrm{~cm}$ and $20-40 \mathrm{~cm}$ soil depths in the five different land use types (Figure 5a). Interestingly, in $20-40 \mathrm{~cm}$ depth soil of grassland, the relative abundance of Basidiomycota was the highest (Figure 5a). From the level of genus, the Fusarium, Mortierella and Tetracladium were the dominant genus in $0-20 \mathrm{~cm}$ and $20-40 \mathrm{~cm}$ soil depths in forest and grassland (Figure $5 \mathrm{~b}$ ). Fusarium and Mortierella were the dominant genus in 0-20 cm and 20-40 cm soil depths in Hylocereus spp., Zanthoxylum planispinum and Zea mays (Figure 5b). Furthermore, Preussia was also the dominant genus at two soil depths of Zea mays (Figure 5b).

At the genus level, the heat map produced by $\mathrm{R}$ also showed the differences of soil fungal community aggregation patterns at $0-20 \mathrm{~cm}$ and $20-40 \mathrm{~cm}$ depths in different land use types (Figure 6). Compared with the other four land use types, the vast majority of the top 30 soil fungal genera in $0-20 \mathrm{~cm}$ and $20-40 \mathrm{~cm}$ depths soil in Zea mays land have higher absolute abundance (Figure 6). In contrast, the absolute abundance of most fungal genera in forest and grassland at $0-20 \mathrm{~cm}$ and $20-40 \mathrm{~cm}$ soil depths was significantly lower than that of the other three different land use types (Figure 6). Besides, we determined the beta diversity to study the effects of different land use types and soil depth on soil fungal communities (Figure 7). The first principal component explained $21.83 \%$ of the total variance, and the second principal component explained $10.79 \%$ of the variance. The points of five different land types were significantly dispersed, indicating that land use type caused the significant change of soil fungal community structure. However, except for Zea mays, the points of $0-20 \mathrm{~cm}$ depths soil and $20-40 \mathrm{~cm}$ depths soil were very concentrated, indicating the similarity of fungal community composition at the two soil depths, and the effect of soil depth on soil fungal structure was not significant. 

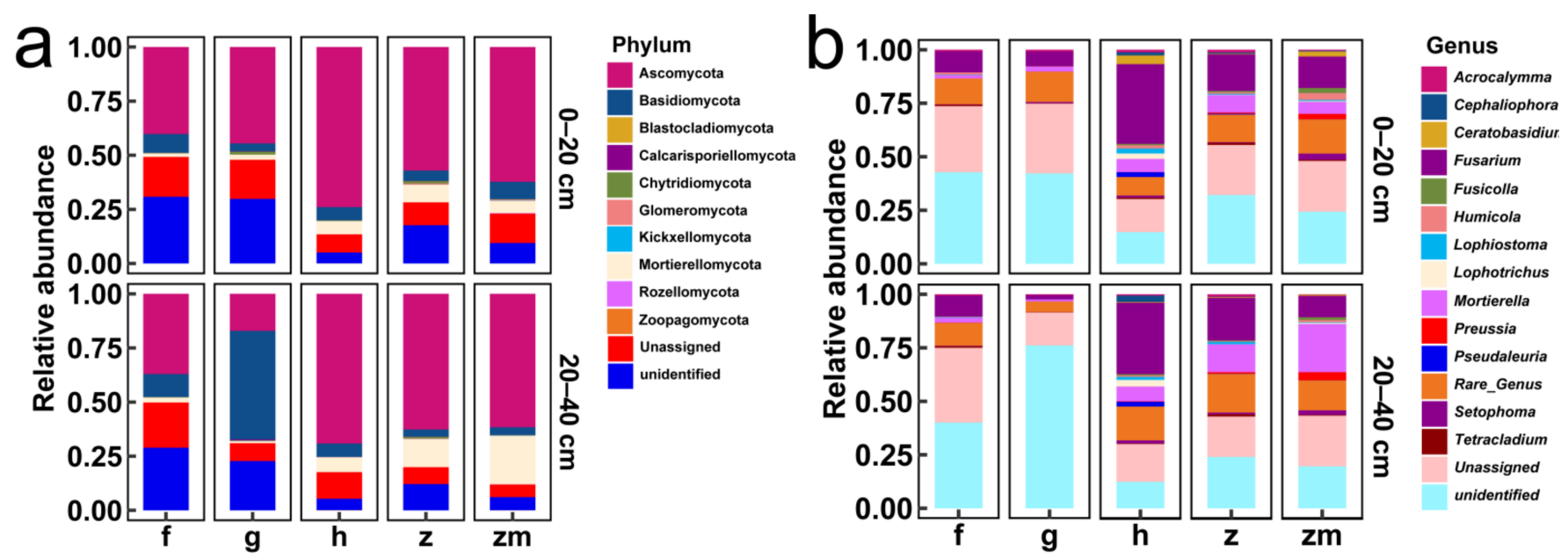

Figure 5. The relative abundance of major fungal phyla in all soil samples $((\mathbf{a}, \mathbf{b})$ represent phylum level and genus level \%, respectively). The abbreviations are described in Figure 1a.

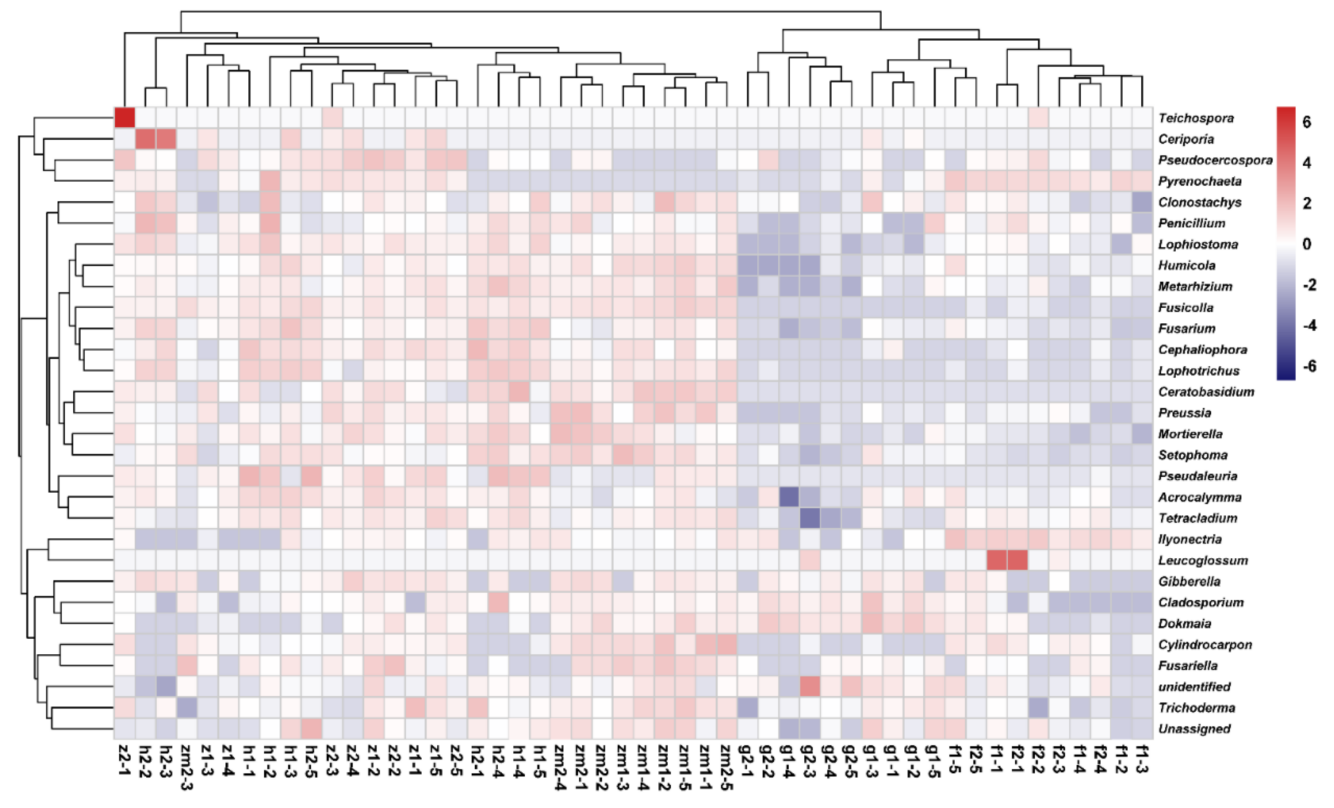

Figure 6. Heat maps of the 30 most abundant fungal genera in different land use types at $0-20 \mathrm{~cm}$ and $20-40 \mathrm{~cm}$ soil depths, the absolute abundance of fungi is expressed by color intensity. The abbreviations are described in Figure 1a. 


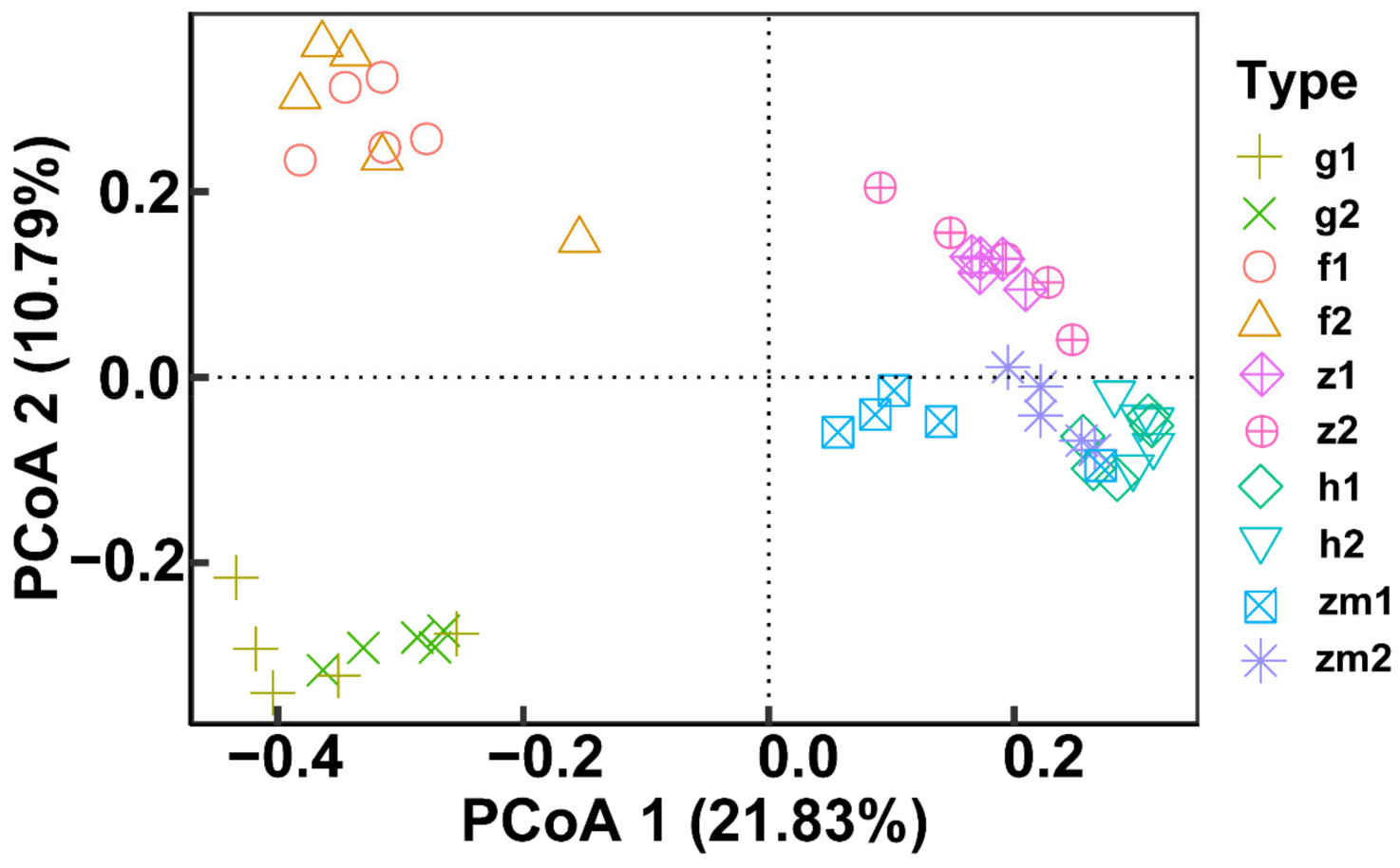

Figure 7. Effect of the different land use types on fungal beta diversity at $0-20 \mathrm{~cm}$ and $20-40 \mathrm{~cm}$ soil depths. Principal coordinate analysis (PCoA) based on Bray-Curtis of all soil fungal communities. The abbreviations are described in Figure $1 \mathrm{a}$.

\subsection{Comparison of Different Fungal Species at 0-20 cm and 20-40 cm Soil Depth in Different Land Use Types}

Histogram of LDA value distribution of soil fungi at different depths in different land use types. Figure S1 showed the significantly different species with LDA score greater than the preset value (the default preset value was 3.0). In the $20-40 \mathrm{~cm}$ depth soil of grassland, the abundance of fungi of only one genus was significantly higher than that of $0-20 \mathrm{~cm}$ depth which was Ochroconis (Figure S1a). In the topsoil layers of Zanthoxylum planispinum, the relative abundance of Glomeromycota and Glomus was significantly higher than that at the soil depths of 20-40 cm (Figure S1b). In Hylocereus spp. land, the relative abundance of Tecladium in 0-20 cm soil was significantly higher than that in 20-40 cm soil (Figure S1c). In Zea mays soil, the relative abundance of Humicola in $0-20 \mathrm{~cm}$ soil layer was significantly higher than that in 20-40 cm soil layer, while the relative abundance of Gibberella in 20-40 cm soil layer was significantly higher than that in 0-20 cm soil layer (Figure S1d). We also found that there were no fungal groups with significant differences in relative abundance in different soil depths of forest.

\subsection{Correlation of Soil Fungal Communities Composition and Diversity with Content of Soil Mineral Elements}

At soil depths of $0-20 \mathrm{~cm}$ and $20-40 \mathrm{~cm}$, there was significant relevance between soil fungal diversity and soil mineral contents of different land use types (Figure S2). We found that at depth of $0-20 \mathrm{~cm}$ soil, the contents of $\mathrm{Cr}, \mathrm{Ni}, \mathrm{Cu}(p<0.05)$ and $\mathrm{Zn}, \mathrm{Cd}$ and $\mathrm{Pb}(p<0.001)$ in grassland were significantly correlated with Shannon index (Figure S2a); the content of $\mathrm{Mg}(p<0.05)$ in forest was significantly related to Chao1 index (Figure S2c). Similarly, the contents of soil $\mathrm{Ni}, \mathrm{Cu}, \mathrm{Cd}$ and $\mathrm{Pb}(p<0.05)$ were closely related to PCoA in Zanthoxylum planispinum (Figure S2e), and in Hylocereus spp., PCoA was closely related to $\mathrm{Mg}$ content ( $p<0.05$ Figure $8 \mathrm{~g}$ ). At soil depths of $20-40 \mathrm{~cm}$, PCoA was closely related to $\mathrm{K}$ content in forest ( $p<0.05$ Figure S2d); in Hylocereus spp. soil, Chao1 was significantly correlated with $\mathrm{K}$ content, but PCoA was significantly correlated with contents of $\mathrm{Cr}(p<0.05), \mathrm{Ni}(p<0.01), \mathrm{Zn}(p<0.05), \mathrm{Cd}(p<0.05)$ and $\mathrm{Pb}(p<0.01$ Figure S2f $)$. We 
also found that Shannon and Chao 1 index was clearly related to K content $(p<0.01)$ and Ni content $(p<0.05)$ in Hylocereus spp. soil (Figure S2h). Morever, in Zea mayssoil, PCoA was significantly correlated with contents of $\mathrm{Cd}$ and $\mathrm{Pb}(p<0.05$ Figure S2j).
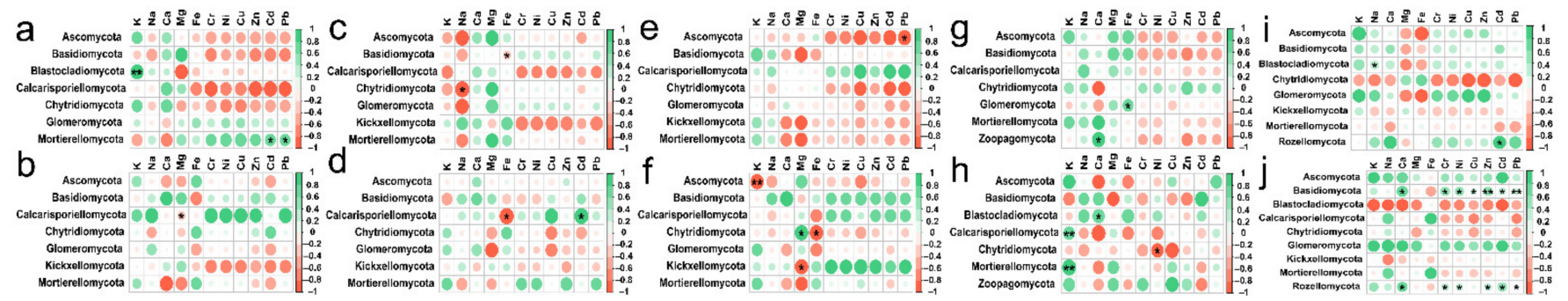

Figure 8. Spearman's Rank correlation coefficients between soil mineral elements content and soil fungal abundance at (a) $0-20 \mathrm{~cm}$ in grassland, (b) $20-40 \mathrm{~cm}$ in grassland, (c) $0-20 \mathrm{~cm}$ in forest, (d) 20-40 cm in forest, (e) 0-20 cm in Zanthoxylum planispinum soil, (f) $20-40 \mathrm{~cm}$ in Zanthoxylum planispinum soil, (g) 0-20 cm in Hylocereus spp. soil, (h) 20-40 cm in Hylocereus spp. soil, (i) $0-20 \mathrm{~cm}$ in Zea mays soil and (j) $20-40 \mathrm{~cm}$ in Zea mays soil. * and ${ }^{* *}$ indicate obvious difference at $p<0.05$ and $p<0.01$ between soil mineral elements content and the abundance of soil fungal phyla.

At soil depths of $0-20 \mathrm{~cm}$, there was a significant positive correlation between $\mathrm{K}$ content and Blastocladiomycota; Na content also had a positive effect on Blastocladiomycota and negative effect on Chytridiomycota; Ca content had a positive impact on Zoopagomycota; Fe content had a positive effect on Glomeromycota and negative effect on Basidiomycota; Content of $\mathrm{Cd}$ and $\mathrm{Pb}$ had a positive effect on Mortierellomycota and Rozellomycota; interestingly, the content of $\mathrm{Cr}, \mathrm{Ni}, \mathrm{Cu}$ and $\mathrm{Zn}$ had no significant effect on the types of fungi (Figure $8 \mathrm{a}, \mathrm{c}, \mathrm{e}, \mathrm{g}, \mathrm{i}$ ). RDA also showed that in topsoil layers, contents of $\mathrm{Ca}$, Fe and $\mathrm{Cu}$ were the main factors affecting the change of soil fungal community in Hylocereus spp. soil; $\mathrm{K}$ was an important factor to affect the changes of soil fungal community in Zanthoxylum planispinum soil; $\mathrm{Cd}$ and $\mathrm{Na}$ were primary factors to affect soil fungal community in Zea mays soil, and $\mathrm{Mg}$ and $\mathrm{Ca}$ were principal considerations affecting the changes of fungal community in grassland and Hylocereus spp. soil (Figure 9a). At 20-40 cm soil depths, K content had a strong negative effect on Ascomycota and a positive effect on Calcarisporiellomycota; Ca content had a negative effect on Blastocladiomycota and Basidiomycota; the content of other heavy metals had a strong negative effect on Basidiomycota and Rozellomycota (Figure $8 \mathrm{~b}, \mathrm{~d}, \mathrm{f}, \mathrm{h}, \mathrm{j}$ ). In addition, in deeper soil, $\mathrm{K}$ was the important factor to affect the changes of soil fungal community in Zea mays soil; content of $\mathrm{Ca}, \mathrm{Fe}$, and $\mathrm{Mg}$ were the main factors affecting the change of soil fungal community in grassland and forest; and heavy metal content were important factors to affect soil fungal community in Zanthoxylum planispinum soil (Figure 9b). 

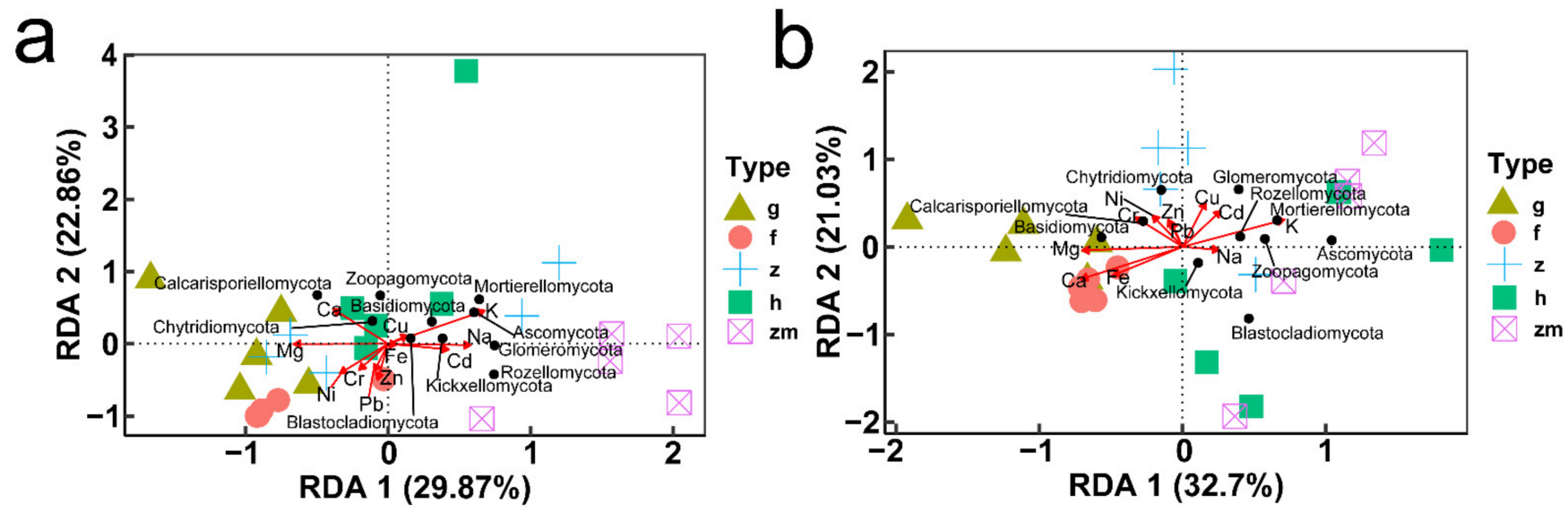

Figure 9. Redundancy analysis (RDA) of relationship between soil mineral elements content (red arrows) and the relative abundance of soil microbial phyla (black points) at (a) $0-20 \mathrm{~cm}$ soil depth and (b) 20-40 cm soil depth, respectively. The abbreviations are described in Figure 1a.

\subsection{Correlation of Soil Fungal Communities Composition and Diversity with Soil Enzyme Activity}

Similarly, our result showed that under the two soil depths, there was significant relevance between soil fungal diversity and soil enzyme activity of different land use types (Figure S3). At 0-20 cm soil depths, Shannon index was related to Inv activity in grassland $(p<0.05$ Figure S3a) and Cat activity in Zea mays soil ( $p<0.05$ Figure S3i), and in Zea mays soil, Chao1 was also closely related to Cat activity $(p<0.01$ Figure S3i). At soil depths of $20-40 \mathrm{~cm}$, the activity of Cat was apparently correlated with Shannon index and PCoA $(p<0.05$ Figure S3b); in Zanthoxylum planispinum, Shannon index was markedly correlated with Alp activity ( $p<0.01$ Figure S3d), and in Hylocereus spp. soil, Chao1 was significantly correlated with Inv activity ( $p<0.05$ Figure S3h).

In different soil depths, the response of fungal phylum level categories of different land use types to the change of soil enzyme activity was also different (Figure 10). In topsoil layers, we found that there was a clear positive correlation between Ure activity and Calcarisporiellomycota and Chytridiomycota; Cat activity had a strong positive effect on Mortierellomycota; interestingly, in forest Ure activity had a positive effect on Ascomycota and Chytridiomycota, but in Hylocereus spp. soil, Ure activity had a strong negative effect on Ascomycota; and Inv activity had no distinct effect on all the phyla levels (Figure 10a,c,e,g,i). In deep soil layers, Inv activity had a strong positive effect on Chytridiomycota; Ure activity had a positive effect on Calcarisporiellomycota and a negative effect on Ascomycota; Alp activity had a positive effect on Ascomycota and a passive effect on Chytridiomycota, Glomeromycota and Kickxellocymota; and Cat activity had a strong effect on Basidiomycota (Figure 10b,d,f,h,j). RDA analysis also showed that in $0-20 \mathrm{~cm}$ soil depth layer, the activities of Inv and Alp were the main factors affecting soil fungal communities in forest, Zanthoxylum planispinum and Zea mays soil; Cat activity was an important factor affecting soil fungal community in Hylocereus spp. soil, such as Zoopagomycota and Ascomycota; Ure mainly affected grassland soil Blastocladiomycota (Figure 11a). At $20-40 \mathrm{~cm}$ soil depths, the activities of Inv and Alp were the main factors affecting the fungal community in forest and Zanthoxylum planispinum soil; Cat was the main factor affecting soil fungal communities in grassland, forest, and Zanthoxylum planispinum land; Ure had a strong positive effect on Zea mays land soil, such as Rozelomycota, Mortierellomycota, and Kickxelomycota (Figure 11b). 


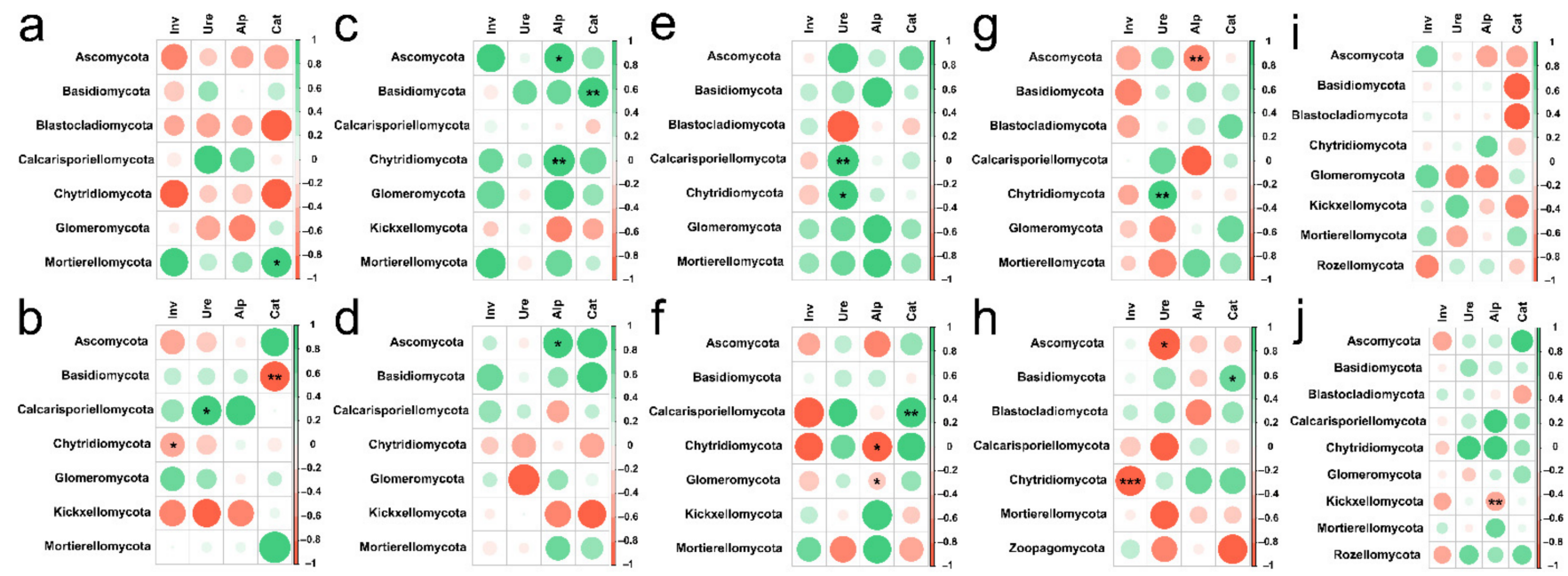

Figure 10. Spearman's Rank correlation coefficients between soil enzyme activity and soil fungal abundance at (a) 0-20 cm in grassland, (b) 20-40 cm in grassland, (c) $0-20 \mathrm{~cm}$ in forest, (d) 20-40 cm in forest, (e) 0-20 cm in Zanthoxylum planispinum soil, (f) $20-40 \mathrm{~cm}$ in Zanthoxylum planispinum soil, (g) 0-20 cm in Hylocereus spp. soil, (h) $20-40 \mathrm{~cm}$ in Hylocereus spp. soil, (i) 0-20 cm in Zea mays soil and (j) $20-40 \mathrm{~cm}$ in Zea mays soil. ${ }^{*}, * *$ and ${ }^{* * *}$ indicate obvious difference at $p<0.05, p<0.01$ and $p<0.001$ between soil enzyme activity and the abundance of soil fungal phyla.
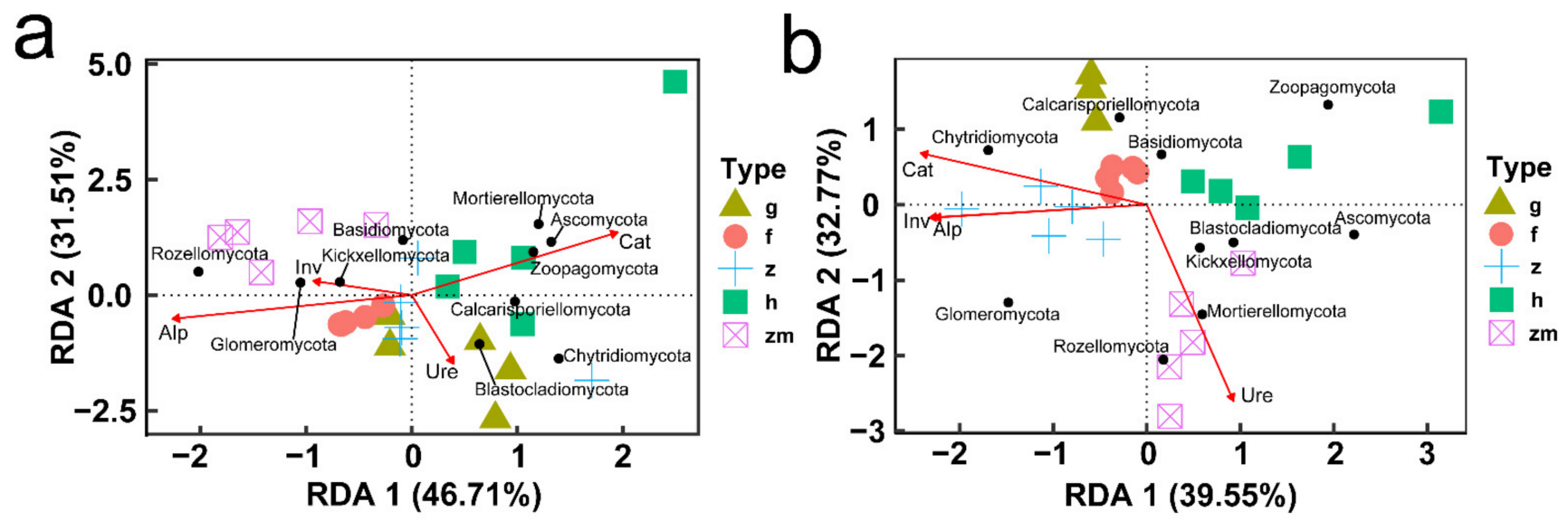

Figure 11. Redundancy analysis (RDA) of relationship between soil enzyme activity (red arrows) and the richness of soil microbial phyla (black points) at (a) 0-20 cm soil depth and (b) 20-40 cm soil depth, respectively. The abbreviations are described in Figure 1a.

The composition and diversity of soil fungal community in different types of land use and soil depth changed, and the change depended on soil mineral elements contents and soil enzyme activity. However, the contribution of these factors to the soil fungal community is still unclear. Therefore, the bonding contributions of soil mineral elements and soil enzyme activities in the fungal communities were also investigated by VPA analysis. The result revealed that land use types, soil depth, soil mineral elements content, and soil enzyme activity explained $12 \%, 0.9 \%, 1.2 \%$, and $0.4 \%$ on the total variations of the fungal community, respectively (Figure 12). 


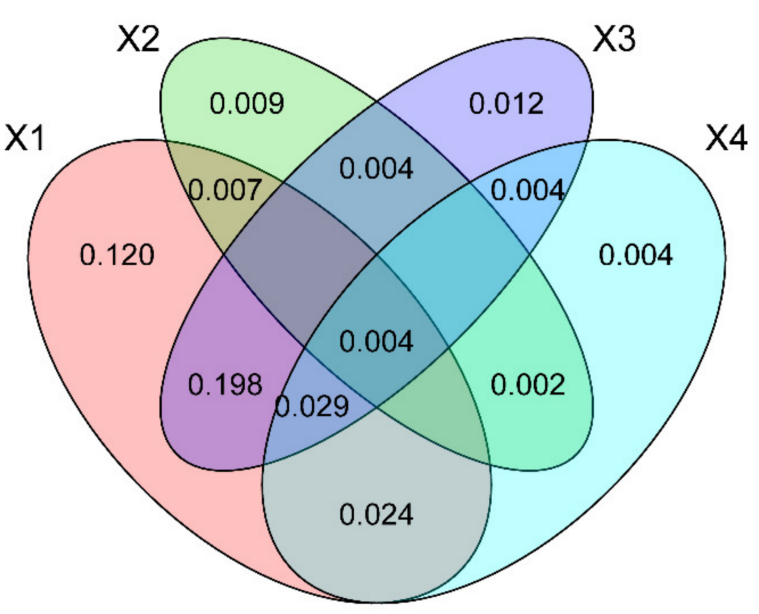

Residuals $=0.604$

Values $<0$ not shown

Figure 12. Variance distribution analysis (VPA) to determine the relative contributions of land use type, soil depth, soil metal element content and soil enzyme activity to soil fungal community structure and diversity. $\mathrm{X} 1=\mathrm{LUT}, \mathrm{X} 2=\mathrm{SD}, \mathrm{X} 3=$ soil metal element content, $\mathrm{X} 4$ = soil enzyme activity. Value represents the significance level when $p<0.0$ not shown.

\section{Discussion}

Different land use types can lead to different ecosystem functions by influencing underground processes, and soil mineral elements can be affected by soil properties and land management and utilization $[35,36]$. It has been reported that grassland reclamation in the karst area reduced soil trace elements $(\mathrm{Cu}, \mathrm{Fe}, \mathrm{Mo}, \mathrm{B})$ and enriched in surface soil [37]. $\mathrm{Li}$ et al., found that the land use history changed the central trend and heterogeneity of soil properties, including $\mathrm{C}, \mathrm{N}, \mathrm{C}: \mathrm{N}, \mathrm{Ca}$, and $\mathrm{K}$ [38]. Similarly, land use patterns affect plant litter, thus changing the microbial activities, leading to changes in soil nutrients, and informing a typical correlation among soil microorganisms, vegetation, soil nutrient, and mineral [39]. In the current study, in two different depths of soil $\mathrm{K}$ content of different land use types from high to low was followed Zanthoxylum planispinum land $>$ Hylocereus spp. land $>$ Zea mays land $>$ forest land > grassland at two different depths of soil. Similar studies also observed that the K content in cultivated soil was higher than the other types of land [40]. Zanthoxylum planispinum and Hylocereus spp. are economic crops with a large amount of fertilizer, which may accelerate nutrient turnover, promote $\mathrm{K}$ accumulation, or increase availability [41]. Yu et al., also confirmed that chemical fertilizers can effectively increase the total $\mathrm{K}$ and $\mathrm{P}$ content in soil [42]. The natural karst environment is rich in $\mathrm{Ca}$, which has a remarkable effect on the soil physical and chemical properties [43]. We found that the Ca content was the highest in grass land at soil depths of $20-40 \mathrm{~cm}$, followed by secondary forest. Studies showed that the organic matter and humic acid of karst soil have strong adsorption and complexation to Ca [44,45]. A large amount of litter in grassland and secondary forest returned to the soil and provided a $\mathrm{C}$ source. The input of litter is related to the richness of the forest. The plant tissue falling from tulip poplar constituted a large amount of organic matter input into the soil, which contributes to the low variability of $\mathrm{C}$ and $\mathrm{N}$ concentration on a small scale, while the $\mathrm{Ca}$ accumulated in plant tissues enables the trees to absorb it from deep soil layers to maintain the effective calcium concentration in topsoil layers, which eventually cause the reduction in local soil Ca variability [46]. Similarly, the contents of $\mathrm{Mg}$ and Fe was highest in the grassland at two different soil depths, while they were reduced in different tillage systems and planting patterns. The possible reason for the decline may include: (1) the coarsening of soil particle composition resulted in the decrease in element adsorption, resulting in the leaching of mineral nutrients, (2) the decomposition of organic matter accelerated, and $\mathrm{pH}$ changed, 
which affected the deposition of elements, (3) Fe was mainly controlled by soil formation and weathering, and the degree of weathering was high in the farming area [41,47]. Our results showed that the five different land management types had no significant effect on $\mathrm{Na}$ content, similar to Yu et al. [41]. The differences in field management methods, such as fertilizer application quantity and mode can lead to variations in soil physical and chemical properties and nutrient availability under different tillage systems and planting modes [48]. Interestingly, we found that soil depth had no significant effect on mineral nutrient contents. However, the content of $\mathrm{Ca}$ and $\mathrm{Fe}$ in $0-20 \mathrm{~cm}$ soil layer was significantly higher than that in the $20-40 \mathrm{~cm}$ soil layer probably because the soil biological activities were frequent in the thick maize roots that contributed to deep absorption. Ca content in the deep soil layer was higher than the shallow layer of grassland, which may be related to the return of grass root biomass and the decrease in surface runoff [49].

Land use types correspond to the changes in soil management, vegetation types and microbial activity. These changes have an important impact on the migration, transformation, and enrichment of soil heavy metals [50,51]. Wilck et al. [52] investigated the soil contents of heavy metals in three land use patterns (cultivated land, forest, and grassland) in Slovakia, and found that the concentrations of heavy metals in forest soil was lowest due to complexity of the organic matter. Moreover, the concentrations of $\mathrm{Cr}, \mathrm{Cu}$, and nickel (Ni) were highest in cultivated soil, while $\mathrm{Cd}$ and $\mathrm{Zn}$ were highest in grassland soil [52]. In addition, it was reported that heavy metals under different land use types affect the soil microbial and enzyme mediated soil C/N cycle in karst areas [53]. Our results suggested that the interaction of LUT $\times$ SD only had a significant effect on $\mathrm{Cu}$ content, and $\mathrm{Cd}$ and $\mathrm{Cu}$ in different types of land and soil layers had significant statistical differences, indicating that $\mathrm{Cd}$ and $\mathrm{Cu}$ were the dominant factors controlling soil quality. The contents of $\mathrm{Cu}$ and $\mathrm{Cd}$ were highest in the top and lower soil layers of Hylocereus spp. and Zanthoxylum planispinum land while lowest in grassland, implying that agricultural activities including the use of chemical fertilizers, exacerbated the accumulation of heavy metals, which was similar to previous studies [54,55].

There was no significant difference in $\mathrm{Cr}, \mathrm{Ni}, \mathrm{Zn}$, and $\mathrm{Pb}$ contents in $0-20 \mathrm{~cm}$ soil layer among the five different types of land use, but the content of these heavy metals was highest in forest in 20-40 cm soil layers, followed by Zanthoxylum planispinum, contrary to the reported studies. The studies showed that a large amount of humus in forest has functional groups and chelating quality, which reduces the bioavailability of heavy metals and increases their content. Since woody plants have more roots, the canopy intercepts and absorbs the deposited heavy metals [56]. Therefore, in the process of land use conversion, the environmental effects and the absorption differences of various plants at different spatial and temporal scales produce different results. In general, the contents of heavy metals in grassland, Hylocereus spp. and Zea mays soil decreased gradually with the increase in soil depth, showing obvious surface enrichment [42], but increased in forest and Zanthoxylum planispinum soil. It was reported that $\mathrm{Cr}$ content was the highest in deep soil of forest land and grassland, possibly due to the poor migration ability of $\mathrm{Cr}$ [57]. The sources and migration characteristics of different heavy metals depend on the type of land use. In a specific ecosystem like karst, the growth of soil microorganisms is affected by vegetation and human activities, and then eventually affects the expression and activity of enzymes [58]. Microorganisms are mostly distributed in the surface soil to decompose the surface litter and root exudates and get more organic matter input [59]. It was reported that soil enzyme activities in temperate grassland and tropical forest, decreased exponentially with depth [60]. The current study found that with the increase in soil depth, the enzyme activity in different types of land gradually decreased. These results were consistent with the findings of Stone et al. [60] and Gelsomino and Azzellino. [61], who believed that increment in the depth resulted in the decreased availability of active substrate and oxygen supply. However, the activities of invertase and urease in the topsoil of grassland and maize were lower than in the deep soil. Grassland as the initial stage of vegetation succession grows rapidly and develops roots. It absorbs a lot of nutrients and improves 
the decomposition of carbohydrates to stimulate the secretion of sucrase in deep soil [62]. Generally, land use can change soil enzyme activities through plants and microorganisms, or indirectly affect soil enzymes through soil characteristics [63]. In the shallow soil, the activities of Inv, Ure, and Alp were the highest in forest or Zanthoxylum planispinum soil, and similar phenomena were also observed in deep soil where activities of Inv, Alp, and Cat were the highest in forest or Zanthoxylum planispinum soiland the lowest in Hylocereus spp. soil. It was proved that nitrogen fixation of trees again, concurrently, the forest is rich in the litter and the more SOM content, the higher the water holding capacity and effective $\mathrm{C}$, which is more conducive to the activities of microorganisms [64]. A study reported that activities of $\mathrm{C}$ and P-related acquisition enzymes increased with the improvement in $\mathrm{N}$ utilization, which might explain the increase in Alp and Inv activities in Zanthoxylum planispinum soil [64]. In addition, Hylocereus spp. was weak in promoting the conversion of invalid $\mathrm{P}$, and effective $\mathrm{P}$ nutrition was appropriately supplemented during the cultivation process. However, Cat activity was not significantly different in the surface soil of each land type. Liu et al. [65] said that surface soil SOC and Ca form insoluble substances, resulting in the same inert c pool decomposition of the soil, which is not conducive to the production of oxidase by microorganisms.

In the present study, with the increase in soil depth, the fungal $\alpha$ diversity index (Shannon and Chao 1) showed a downward trend, and the difference was the most significant in the maize field which was consistent with previous studies $[66,67]$. We also found that except for Zea mays soil, the contribution rate of soil depth of the other four land use types to the change of soil fungal community was low. Although some studies showed that there was a little difference between fungal community composition/diversity and soil depth, in the Zea mays soil system in karst area, soil depth was the main driving factor of fungal community composition and diversity [68]. The factors affecting fungal diversity are soil management and nutrient level [69]. Our results showed that the Chao1 and Shannon indexes at five different land use types of soil fungal communities were significantly different at 0-20 $\mathrm{cm}$ and $20-40 \mathrm{~cm}$ soil depths, and the $\alpha$ diversity index was the highest in Zanthoxylum planispinum soil and lowest in Hylocereus spp. soil. Studies discussed that the ACE, Chao 1 and Shannon indexes of soil fungi in natural shrubs were greater than those in artificial forest and grassland which indicated the importance of vegetation restoration to microbial diversity [70]. The distance of PCoA also showed that land use type mainly had a significant impact on soil fungal community. Different land use types have obvious effects on the structure and diversity of soil fungal community in Karst and non-karst areas which were consistent with our results [71,72]. It was reported that under high-intensity management, soil permeability and nutrient content were increased, which provided a suitable growth environment for soil fungi and improved fungal diversity [73]. However, excessive $C$ and $\mathrm{N}$ input caused by high-intensity fertilization could reduce soil microbial diversity, which might explain the lowest fungal diversity in Hylocereus spp. and Zea mays soil [74].

In different land use patterns, the characteristics of soil fungal communities changed in the karst area. The findings of Cheng et al., were consistent with our results that Ascomycota and Basidiomycota were the dominant phyla in different wetlands and cultivated land, and Fusarium was the most dominant genus in the corn field and paddy field in karst [71]. Most of the differences in soil fungal composition are related to soil properties. From grassland and forest to agricultural management land, the abundance of Basidiomycetes decreased, while the abundance of Ascomycota was increased. Ascomycota was mainly involved in the degradation of organic matter and the assimilation of root exudates [75]. Previous studies had investigated that the increase in litter was conducive to the transfer of Basidiomycota to Ascomycota [76]. As an important source of soil microbial nutrients, litter plays an important role in the composition and structure of the microbial community. In addition, the abundance of coccidiota in Zanthoxylum planispinum soiland other three types of soil increased significantly. Glomeromycota can form arbuscular mycorrhiza with plants and promote the host to absorb nutrients which indicated that crops need more nutrients [77]. Therefore, the relative abundance of different types of soil fungi was 
different, indicating the differences in root residues, secretions, and crop management of different plants, which will affect soil physical and chemical properties and then change the species composition and structure of microorganisms.

In the current study, heavy metal content and $\alpha$ and $\beta$ Diversity of soil fungi were significantly negatively correlated at the soil depths of $0-20 \mathrm{~cm}$ in grassland and pepper field, and the results were the same at depths of $20-40 \mathrm{~cm}$ soil of Zanthoxylum planispinum. Some studies have shown that soil heavy metals can reduce the soil fungal diversity [78]. $\mathrm{Mg}$ and $\mathrm{K}$ contents had a clear positive effect on soil fungal diversity in forest and Hylocereus spp. soil, which may be related to the lack of related elements in these two land types in karst areas. Plenty of studies had confirmed that soil carbon, nitrogen, phosphorus, and $\mathrm{pH}$ were the main driving factors to change soil fungal community, it was not clear whether soil mineral nutrients would affect the soil fungal community structure [79]. The results of RDA analysis demonstrated that the relationship between fungal phylum communities and soil mineral content in different land use types was different. In different soil depths of Zea mays and Hylocereus spp. soil, the dominant fungi were significantly correlated with $\mathrm{K}$ and Na. Pan et al., found that total $\mathrm{K}$ was positively correlated with Ascomycota and Basidiomycota, and soil $\mathrm{K}$ could provide nutrients for soil microorganisms [80]. There was a significant positive correlation between Basidiomycetes and content of $\mathrm{Mg}$, $\mathrm{Ca}$ and Fe at the depths of $20-40 \mathrm{~cm}$ soil in grassland, which was consistent with previous studies on the relationship between soil fungal community composition and soil Fe content [81]. The correlation between soil mineral nutrients and fungal community structure in karst areas was different in five land types, which may be caused by different soil environments in the karst region.

Fungi are considered to be the main producers of soil enzymes. It was reported that the relationship between soil fungal community diversity and soil enzyme activity [82,83]. In our study, soil fungi with different use types and depths were correlated with different kinds of enzymes. Inv and Alp mainly affect the fungal community in forest and Zanthoxylum planispinum soil. Studies have shown that alkaline phosphatase was mainly related to the fungal composition of grassland topsoil and mature forest subsoil [83]. Rotation and fertilization will increase the enzymes involved in organic carbon, nitrogen mineralization and decomposition. Our results showed that Ure and Inv activity mainly affected the composition and diversity of fungi in Zanthoxylum planispinum and Zea mays soil [84]. Therefore, farmland management can regulate the effect of soil fungal communities on soil enzyme activity. Similarly, we also found that Inv was positively correlated with Glomeromycota and Kickxellomycota. Therefore, these two fungi might be the main fungal species for the decomposition of soil organic matter in forest and grassland. However, some studies have shown that the relativity between soil enzyme activity and abiotic factors is greater than that with fungal community, so it is necessary to further study the relationship between soil enzyme and abiotic factors such as soil physical and chemical properties [85].

\section{Conclusions}

Rational land use is conducive to improving soil nutrients and soil fungal communities in karst areas. In this study, land use type and soil depth significantly affected soil mineral elements contents, soil enzyme activity, and fungal community. Specifically, land use types had significant effects on the contents of soil $\mathrm{K}, \mathrm{Mg}, \mathrm{Fe}, \mathrm{Cu}$ and $\mathrm{Cr}$; however, soil depth had no significant effect on soil mineral elements contents. Both land use type and depth significantly affected the invertase, urease, alkaline phosphatase, and catalase activity. In addition, Shannon and Chao1 index of soil fungal community was affected by different land use types and depths. Ascomycota, Basidiomycota, and Mortierellomycota were the dominant phyla at $0-20 \mathrm{~cm}$ and $20-40 \mathrm{~cm}$ soil depths on five different land types. However, soil depth had no significant effect on the soil fungal structure. This might be because smallscale environmental variation in the karst areas was not the dominant factor in changing the fungal community structure. Soil mineral elements content, enzyme activity, and soil fungal community in the karst area were strongly affected by land use type and soil depth. 
Our findings provided a theoretical basis for the rational use of limited land in Karst's fragile ecological environment. More importantly, in recent years, the local government has encouraged farmers to grow different cash crops, which has led to changes in land types and management. The current research can help to guide the selection of appropriate land use types for crop planting and nutrient management in karst areas based on soil fungal community structure.

Supplementary Materials: The following are available online at https:/ /www.mdpi.com/article/10 .3390 /ijerph19053120/s1, Figure S1: LDA of soil fungi with statistical difference between 0-20 cm and $20-40 \mathrm{~cm}$ soil depth in different land use types; Figure S2: Spearman's Rank correlation coefficients between soil mineral elements content and soil fungal community variety; Figure S3: Spearman's Rank correlation coefficients between soil enzyme activity and soil fungal community variety; Table S1: Results of two-way ANOVA for the effects of land use types (LUT) and soil depths (SD) on soil contents of $\mathrm{K}, \mathrm{Na}, \mathrm{Ca}, \mathrm{Mg}$ Fe ; Table S2: Results of two-way ANOVA for the effects of land use types (LUT) and soil depths (SD) on soil contents of $\mathrm{Cr}, \mathrm{Ni}, \mathrm{Cu}, \mathrm{Zn}, \mathrm{Cd}, \mathrm{Pb}$; Table S3: Results of two-way ANOVA for the effects of land use types (LUT) and soil depths (SD) on enzyme activities; Table S4: Results of two-way ANOVA for the effects of land use types (LUT) and soil depths (SD) on Shannon and Chao1.

Author Contributions: Conceptualization, Y.Y.; experimental design and methodology, J.W. and Y.Y.; resource, J.G., W.H., J.L. and X.K.; investigation, J.G., W.H., X.K., L.W., X.C., C.C. and Y.L.; statistical analyses, J.G., J.W., M.T., J.L., K.M. and R.Z.; writing-original draft preparation, J.G. and W.H., writing-review and editing, K.M. and J.W.; supervision, Y.Y.; project administration, Y.Y. and J.W.; funding acquisition, Y.Y. and J.W. All authors have read and agreed to the published version of the manuscript.

Funding: This research was financially supported by Program for the Joint Fund of the National Natural Science Foundation of China and the Karst Science Research Center of Guizhou province (Grant No. U1812401), the Fundamental Research Funds for the Central Universities (lzujbky2021-ey01, lzujbky-2021-kb12) in Lanzhou University, Changjiang Scholars and innovative Research Team in University (IRT_17R50), the Open Project of State Key Laboratory of Plateau Ecology and Agriculture, Qinghai University (2021-KF-02), Lanzhou University “Double First-Class" guiding special project-team construction fund-scientific research start-up fee standard (561119206), Technical service agreement on research and development of beneficial microbial agents for Alpine Rhododendron (071200001).

Institutional Review Board Statement: Not applicable.

Informed Consent Statement: Not applicable.

Data Availability Statement: Not applicable.

Conflicts of Interest: The authors state no conflict of interest.

\section{References}

1. Sweeting, M.M. Karst in China. In Karst in China Series: Springer Series in Physical Environment; Springer: Berlin/Heidelberg, Germany, 1995; Volume 15.

2. Green, S.M.; Dungait, J.; Tu, C.; Buss, H.L.; Sanderson, N.; Hawkes, S.J.; Xing, K.; Yue, F.; Hussey, V.L.; Peng, J. Soil functions and ecosystem services research in the Chinese karst Critical Zone. Chem. Geol. 2019, 527, 119107. [CrossRef]

3. Yang, X.Q.; Hu, B.Q. Quality Characteristics of Soils in Karst Rocky-Desertified Areas With Ecosystem Under Restoration Succession-A Case Study of Chengjiang Subwatershed,Du'an County, Guangxi. J. Ecol. Rural Environ. 2009, 25, 1-5.

4. Richardson, M.; Kumar, P. Critical Zone services as environmental assessment criteria in intensively managed landscapes. Earth's Future 2017, 5, 617-632. [CrossRef]

5. Vitousek, P.M.; Aber, J.D.; Howarth, R.W.; Likens, G.E.; Matson, P.A.; Schindler, D.W.; Schlesinger, W.H.; Tilman, D.G. Human alteration of the global nitrogen cycle: Sources and consequences. Ecol. Appl. 1997, 7, 737-750. [CrossRef]

6. Xiao, S.; Wei, Z.; Ye, Y.; Jie, Z.; Wang, K. Soil aggregate mediates the impacts of land uses on organic carbon, total nitrogen, and microbial activity in a Karst ecosystem. Sci. Rep. 2017, 7, 41402. [CrossRef] [PubMed]

7. Chen, X.; Su, Y.; He, X.; Wei, Y.; Wei, W.; Wu, J. Soil bacterial community composition and diversity respond to cultivation in Karst ecosystems. World J. Microbiol. Biotechnol. 2012, 28, 205-213. [CrossRef] 
8. He, S.; Guo, L.; Niu, M.; Miao, F.; Jiao, S.; Hu, T.; Long, M. Ecological diversity and co-occurrence patterns of bacterial community through soil profile in response to long-term switchgrass cultivation. Sci. Rep. 2017, 7, 3608. [CrossRef] [PubMed]

9. Wang, J.F.; Xie, S.Y.; Feng, H.F.; Yuan, W.H.; Wang, C.X. Characteristic Study of Soil Microbe under Different Land-use Types in Chongqing Karst Region. J. Environ. Sci. Manag. 2010, 35, 150-154.

10. Makoi, J.; Ndakidemi, P.A. Selected soil enzymes: Examples of their potential roles in the ecosystem. Afr. J. Biotechnol. 2018, 7, 181-191.

11. Aon, M.A.; Colaneri, A.C. Temporal and spatial evolution of enzymatic activities and physico-chemical properties in an agricultural soil. Appl. Soil Ecol. 2011, 18, 255-270. [CrossRef]

12. Wang, X.; Fan, J.; Xing, Y.; Xu, G.; Wang, H.; Jian, D.; Wang, Y.; Zhang, F.; Li, P.; Li, Z. The Effects of Mulch and Nitrogen Fertilizer on the Soil Environment of Crop Plants. Adv. Agron. 2019, 153, 121-173.

13. Wu, J.; Wang, H.; Li, G.; Ma, W.; Xu, G. Vegetation degradation impacts soil nutrients and enzyme activities in wet meadow on the Qinghai-Tibet Plateau. Sci. Rep. 2020, 10, 21271. [CrossRef] [PubMed]

14. Dick, R.P.; Kandeler, E. Enzymes in soils. Encycl. Soils Environ. 2005, 448-456.

15. Jílková, V.; Jandová, K.; Kukla, J. Responses of microbial activity to carbon, nitrogen, and phosphorus additions in forest mineral soils differing in organic carbon content. Biol. Fertil. Soils 2021, 57, 513-521. [CrossRef]

16. Maithani, S.; Pal, M.; Maity, A.; Pradhan, M. Isotope selective activation: A new insight into the catalytic activity of urease. RSC Adv. 2017, 7, 31372-31376. [CrossRef]

17. Khadem, A.; Raiesi, F. Response of soil alkaline phosphatase to biochar amendments: Changes in kinetic and thermodynamic characteristics. Geoderma 2019, 337, 44-54. [CrossRef]

18. Zhang, X.; Liu, S.; Li, X.; Wang, J.; Ding, Q.; Wang, H.; Tian, C.; Yao, M.; An, J.; Huang, Y. Changes of soil prokaryotic communities after clear-cutting in a karst forest: Evidences for cutting-based disturbance promoting deterministic processes. FEMS Microbiol. Ecol. 2016, 92, fiw026. [CrossRef]

19. Cardinale, B.J.; Wrigh, J.P.; Cadotte, M.W.; Carroll, I.T.; Hector, S. Impacts of plant diversity on biomass production increase through time because of species complementarity. Proc. Nat. Acad. Sci. USA 2007, 104, 18123-18128. [CrossRef]

20. Narottam, S.; Mollah, M.Z.I.; Alam, M.F.; Rahman, S.M. Seasonal investigation of heavy metals in marine fishes captured from the Bay of Bengal and the implications for human health risk assessment. Food Control 2016, 70, 110-118.

21. Liu, R.; Zhang, Z.; Shen, J.; Wang, Z. Community characteristics of bryophyte in Karst caves and its effect on heavy metal pollution: A case study of Zhijin Cave, Guizhou Province. Biodivers. Sci. 2018, 26, 1277-1288. [CrossRef]

22. Ping, C.; Ruan, Y.; Wang, S.; Liu, X.; Lian, B. Effects of organic mineral fertiliser on heavy metal migration and potential carbon sink in soils in a karst region. Chin. J. Geochem. 2017, 36, 539-543.

23. Jiao, W.; Ouyang, W.; Hao, F.; Liu, B.; Wang, F. Geochemical variability of heavy metals in soil after land use conversions in Northeast China and its environmental applications. Environ. Sci. Processes Impacts 2014, 16, 924-931. [CrossRef]

24. Chrastný, V.; Komárek, M.; Procházka, J.; Pechar, L.; Vaněk, A.; Penížek, V.; Farka, J. 50 years of different landscape management influencing retention of metals in soils. J. Geochem. Explor. 2012, 115, 59-68. [CrossRef]

25. Qi, D.; Wieneke, X.; Zhou, X.; Jiang, X.; Xue, P. Succession of plant community composition and leaf functional traits in responding to karst rocky desertification in the Wushan County in Chongqing, China. Community Ecol. 2017, 18, 157-168. [CrossRef]

26. Li, Y.; Han, C.; Sun, S.; Zhao, C. Effects of Tree Species and Soil Enzyme Activities on Soil Nutrients in Dryland Plantations. Forests 2021, 12, 1153. [CrossRef]

27. Zhong, Y.; Yan, W.; Wang, R.; Wang, W.; Shangguan, Z.P. Decreased occurrence of carbon cycle functions in microbial communities along with long-term secondary succession. Soil Biol. Biochem. 2018, 123, 207-217. [CrossRef]

28. Caporaso, J.G.; Kuczynski, J.; Stombaugh, J.; Bittinger, K.; Bushman, F.D.; Costello, E.K.; Fierer, N.; Peña, A.G.; Goodrich, J.K. QIIME allows analysis of high-throughput community sequencing data. Nat. Methods 2010, 7, 335-336. [CrossRef]

29. Bengtsson-Palme, J.; Ryberg, M.; Hartmann, M.; Branco, S.; Wang, Z.; Godhe, A. Improved software detection and extraction of ITS1 and ITS2 from ribosomal ITS sequences of fungi and other eukaryotes for analysis of environmental sequencing data. Methods Ecol. Evol. 2013, 4, 914-919. [CrossRef]

30. Schloss, P.D.; Westcott, S.L.; Ryabin, T.; Hall, J.R.; Hartmann, M.; Hollister, E.B.; Lesniewski, R.A.; Oakley, B.B.; Parks, D.H. Introducing mothur: Open-source, platform-independent, community-supported software for describing and comparing microbial communities. Appl. Environ. Microb. 2009, 75, 7537-7541. [CrossRef]

31. Kõljalg, U.; Nilsson, R.H.; Abarenkov, K.; Tedersoo, L.; Taylor, A.; Bahram, M.; Bates, S.; Bruns, T.; Bengtsson-Palme, J.; Callaghan, T. Towards a unified paradigm for sequence-based identification of Fungi. Mol. Ecol. 2013, 22, 5271-5277. [CrossRef]

32. Edgar, R.C. UPARSE: Highly accurate OTU sequences from microbial amplicon reads. Nat. Methods 2013, 10, 996-998. [CrossRef] [PubMed]

33. Hou, W.P.; Wang, J.F.; Nan, Z.B. Epichloë gansuensis endophyte-infection alters soil enzymes activity and soil nutrients at different growth stages of Achnatherum inebrians. Plant Soil 2020, 455, 227-240. [CrossRef]

34. Zhang, C.; Liu, G.B.; Xue, S.; Lin, Z. Rhizosphere soil microbial activity under different vegetation types on the Loess Plateau, China. Geoderma 2011, 161, 115-125. [CrossRef]

35. Macdonald, C.A.; Thomas, N.; Robinson, L.; Tate, K.R.; Ross, D.J.; Dando, J.; Singh, B.K. Biochemical and molecular responses of the soil microbial community after afforestation of pastures with Pinus radiata. Soil Biol. Biochem. 2009, 41, 1642-1651. [CrossRef] 
36. Liao, Q.; Nan, Z.; Wang, S.; Huang, H.; Ding, H. Spatial variability and abundance evaluation of available microelements in the middle reaches of Heihe River. J. Arid. Land Resour. Environ. 2012, 13, 187.

37. Chen, C.; Yang, F.; Liu, H.; Yao, H.; Song, G. Effects and evaluation of soil trace elements after grassland converted into cropland in Guizhou karst area. Trans. Chin. Soc. Agric. Eng. 2013, 29, 230-237.

38. Li, J.; Richter, D.D.; Mendoza, A.; Heine, P. Effects of land-use history on soil spatial heterogeneity of macro- and trace elements in the Southern Piedmont USA. Geoderma 2010, 156, 60-73. [CrossRef]

39. Song, M.; Zou, D.; Hu, D.U.; Peng, W.; Zeng, F.; Tan, Q.; Fan, F. Characteristics of soil microbial populations in depressions between karst hills under different land use patterns. Chin. J. Appl. Ecol. 2013, 24, 2471-2478.

40. Feyisa, D.; Kissi, E.; Kebebew, Z. Rethinking Eucalyptus globulus Labill. Based Land Use Systems in Smallholder Farmers Livelihoods: A Case of Kolobo Watershed, West Shewa, Ethiopia. Nephron Clin. Pract. 2018, 37, 57-68. [CrossRef]

41. Yu, Y.H.; Yang, D.; Zhong, X. Characteristics of Soil Affinity Elements of Typical Land Use Types in the Rocky Desertification Area of Central Guizhou. Earth Environ. 2019, 47, 429-435.

42. Yang, Y.; Hu, D.; Song, T.; Peng, W.; Zeng, F.; Wang, K.; Lu, S.Y.; Fan, F.; Lu, C.Y. Characteristics of soil fertility in different ecosystems in depressions between karst hills. Acta Ecol. Sin. 2013, 33, 7455-7466. [CrossRef]

43. Chen, T.; Wei, X.; Guan, G.; Li, Z.Y. Impact of Different Land Use Types on Soil Calcium in Northern Guangdong. Trop. Geogr. 2014, 15, 61-68.

44. Chen, J.R.; Cao, J.H.; Liang, Y.; Yang, H. Relationship of the humus components and the calcium form with the development of limestone soil. Carsol. Sin. 2012, 31, 7-11.

45. Xie, L.P.; Wang, S.J.; Xiao, D.A. Ca Covariant Relation in Plant-soil System in a Small Karst Catshment. Earth Environ. 2007, 1, 26-32.

46. Fraterrigo, J.M.; Turner, M.G.; Pearson, S.M.; Dixon, P. Effects of Past Land Use on Spatial Heterogeneity of Soil Nutrients in Southern Appalachian Forests. Ecol. Monogr. 2005, 75, 215-230. [CrossRef]

47. Han, M.R.; Song, T.Q.; Peng, W.X.; Huang, G.Q.; Shi, W.W. Compositional characteristics and roles of soil mineral substances in depressions between hills in karst region China. J. Appl. Ecol. 2012, 23, 685-693.

48. Liu, X.L.; He, Y.Q.; Zhang, H.L.; Schroder, J.K.; Li, C.L.; Zhou, J.; Zhang, Z.Y. Impact of Land Use and Soil Fertility on Distributions of Soil Aggregate Fractions and Some Nutrients. Pedosphere 2010, 20, 666-673. [CrossRef]

49. Negasa, D.J. Effects of Land Use Types on Selected Soil Properties in Central Highlands of Ethiopia. Appl. Environ. Soil Sci. 2020, 2020, 7026929. [CrossRef]

50. Liu, S.; Fu, J.P.; Cai, X.; Zhou, J.; Dang, Z.; Zhu, R. Effect of Heavy Metals Pollution on Ecological Characteristics of Soil Microbes: A Review. Ecol. Environ. Sci. 2018, 27, 1173-1178.

51. Du, J.Y.; Tu, C.L.; Sheng, M.Y.; Cui, L.F.; Chen, Z.Y.; Zhang, L.K. Effect of Land Use Change on Microbial Community Structure in Central Guizhou Province. J. Sichuan Agric. Univ. 2018, 36, 350-356.

52. Wilcke, W.; Krauss, M.; Kobza, J. Concentrations and forms of heavy metals in Slovak soils. J. Plant Nutr. Soil Sci. 2010, 168, 676-686. [CrossRef]

53. Li, Q.; Hu, Q.; Zhang, C.; Jin, Z. Effects of Pb, Cd, Zn, and Cu on Soil Enzyme Activity and Soil Properties Related to Agricultural Land-Use Practices in Karst Area Contaminated by Pb-Zn Tailings. Pol. J. Environ. Stud. 2018, 27, 2623-2632. [CrossRef]

54. Jia, Y.N.; Yuan, D.X. Effects of Land Use Changes on Trace Elements of Karst Soil in Shuicheng Basin. J. Soil Sci. 2007, 6, 1174-1177.

55. Thinh, N.V.; Akinori, O.; Hoang, N.T.; Anh, N.D.; Yen, T.T.; Kiyoshi, K. Arsenic and Heavy Metal Contamination in Soils under Different Land Use in an Estuary in Northern Vietnam. Int. J. Environ. Res. Public Health 2016, 13, 1091.

56. Ouyang, W.; Shan, Y.; Hao, F.; Lin, C. Differences in soil organic carbon dynamics in paddy fields and drylands in northeast China using the CENTURY model. Agric. Ecosyst. Environ. 2014, 194, 38-47. [CrossRef]

57. Zheng, R.; Zhao, J.; Zhou, X.; Chao, M.A.; Wang, L.; Gao, X. Land Use Effects on the Distribution and Speciation of Heavy Metals and Arsenic in Coastal Soils on Chongming Island in the Yangtze River Estuary, China. Psedosphere 2016, 56, 74-84. [CrossRef]

58. Sun, C.L.; Wang, Y.W.; Wang, C.J.; Li, Q.J.; Wu, Z.H.; Yuan, D.S.; Zhang, J.L. Effects of land use conversion on soil extracellular enzyme activity and its stoichiometric characteristics in karst mountainous. Acta Ecol. Sin. 2021, 41, 4140-4149.

59. Gocke, M.I.; Huguet, A.; Derenne, S.; Kolb, S.; Dippold, M.A.; Wiesenberg, G. Disentangling interactions between microbial communities and roots in deep subsoil. Sci. Total Environ. 2017, 575, 135-145. [CrossRef]

60. Stone, M.M.; Deforest, J.L.; Plante, A.F. Changes in extracellular enzyme activity and microbial community structure with soil depth at the Luquillo Critical Zone Observatory. Soil Biol. Biochem. 2014, 75, 237-247. [CrossRef]

61. Gelsomino, A.; Azzellino, A. Multivariate analysis of soils: Microbial biomass, metabolic activity, and bacterial-community structure and their relationships with soil depth and type. J. Plant Nutr. Soil Sci. 2011, 174, 381-394. [CrossRef]

62. Hao, C.; Pan, L.; Li, W.; Yang, L.; Li, D. Determinants of soil extracellular enzyme activity in a karst region, southwest China. Eur. J. Soil Biol. 2017, 80, 69-76.

63. Wallenius, K.; Rita, H.; Mikkonen, A.; Lappi, K.; Lindstr, M.K.; Hartikainen, H.; Raateland, A.; Niemi, R.M. Effects of land use on the level, variation and spatial structure of soil enzyme activities and bacterial communities. Soil Biol. Biochem. 2011, 43, 1464-1473. [CrossRef]

64. Keeler, B.L.; Hobbie, S.E.; Kellogg, L.E. Effects of Long-Term Nitrogen Addition on Microbial Enzyme Activity in Eight Forested and Grassland Sites: Implications for Litter and Soil Organic Matter Decomposition. Ecosystems 2009, 12, 1-15. [CrossRef]

65. Liu, L.; Chen, H.; Li, D.; Liang, S. Changes of soil hydrolytic and oxidized enzyme activities under the process of vegetation restoration in a karst area, southwest china. Acta Sci. Circumstantiae 2017, 37, 3528-3534. 
66. Schlatter, D.C.; Kendall, K.; Bryan, C.; Huggins, D.R.; Timothy, P. Fungal community composition and diversity vary with soil depth and landscape position in a no-till wheat-based cropping system. FEMS Microbiol. Ecol. 2018, 7, fiy098. [CrossRef] [PubMed]

67. Zhao, H.; Zheng, W.; Zhang, S.; Gao, W.; Fan, Y. Soil Microbial Community Variation with Time and Soil Depth in Eurasian Steppe (Inner Mongolia, China). Ann. Microbiol. 2021, 71, 21. [CrossRef]

68. Ko, D.; Yoo, G.; Yun, S.T.; Jun, S.C.; Chung, H. Bacterial and fungal community composition across the soil depth profiles in a fallow field. J. Ecol. Environ. 2017, 41, 34. [CrossRef]

69. Qin, H.; Li, C.X.; Ren, Q. Effects of different land use patterns on soil bacterial and fungal biodiversity in the hydro-fluctuation zone of the Three Gorges Reservoir region. Acta Ecol. Sin. 2017, 37, 3494-3504.

70. Yang, Y.; Dou, Y.; Huang, Y.; An, S. Links between Soil Fungal Diversity and Plant and Soil Properties on the Loess Plateau. Front. Micro. 2017, 8, 2198. [CrossRef]

71. Cheng, Y.Y.; Jin, Z.J.; Wang, X.T.; Jia, Y.H.; Zhou, J.B. Effect of Land-use on Soil Fungal Community Structure and Associated Functional Group in Huixian Karst Wetland. China Environ. Sci. 2020, 41, 4294-4304.

72. Wang, G.; Liu, Y.; Cui, M.; Zhou, Z.; Zhou, J. Effects of secondary succession on soil fungal and bacterial compositions and diversities in a karst area. Plant Soil 2021. [CrossRef]

73. Sui, X.; Zhang, R.T.; Xu, N. Fungal community structure of different degeneration Deyeuxia angustifoliawetlands in Sanjiang Plain. Environ. Sci. 2016, 37, 3598-3605.

74. Geisseler, D.; Scow, K.M. Long-term effects of mineral fertilizers on soil microorganisms-a review. Soil Biol. Biochem. 2014, 75, 54-63. [CrossRef]

75. Mylène, H.; Patricia, L.; Julien, G.; Zahar, H. Plant host habitat and root exudates shape fungal diversity. Mycorrhiza 2018, 28, 451-463.

76. Peng, D.; Xuan, Y.; Le, H.; Liu, J.; Zhong, Z. Effects of stand age and soil properties on soil bacterial and fungal community composition in Chinese pine plantations on the Loess Plateau. PLoS ONE 2017, 12, e0186501.

77. Haug, I.; Lempe, J.; Homeier, J.; Wei, M.; Setaro, S.; Oberwinkler, F.; Kottke, I. Graffenrieda emarginata (Melastomataceae) forms mycorrhizas with Glomeromycota and with a member of the Hymenoscyphus ericae aggregate in the organic soil of a neotropical mountain rain forest. Can. J. Bot. 2004, 82, 340-356. [CrossRef]

78. Chodak, M.; Gołębiewski, M.; Morawska-Płoskonka, J.; Kuduk, K.; Niklińska, M. Diversity of microorganisms from forest soils differently polluted with heavy metals. Appl. Soil Ecol. 2013, 64, 7-14. [CrossRef]

79. Xue, C.; Penton, C.R.; Zhu, C.; Chen, H.; Duan, Y.; Peng, C.; Guo, S.; Ling, N.; Shen, Q. Alterations in soil fungal community composition and network assemblage structure by different long-term fertilization regimes are correlated to the soil ionome. Biol. Fertil. Soils 2018, 54, 95-106. [CrossRef]

80. Pan, X.; Zhang, S.; Zhong, Q.; Gong, G.; Wang, G.; Guo, X.; Xu, X. Effects of soil chemical properties and fractions of Pb, Cd, and Zn on bacterial and fungal communities. Sci. Total Environ. 2020, 715, 136901-136904. [CrossRef]

81. Benedicte, B.; María, U.J.; Zimmerman, J.K.; Thompson, J.; Jonathan, W.L. Long-lasting effects of land use history on soil fungal communities in second-growth tropical rain forests. Ecol. Appl. 2016, 26, 1881-1895.

82. Huang, M.; Fu, H.; Kong, X.; Ma, L.; Liu, C.; Fang, Y.; Zhang, Z.; Song, F.; Yang, F. Effects of Fertilization Methods on Chemical Properties, Enzyme Activity, and Fungal Community Structure of Black Soil in Northeast China. Diversity 2020, 12, 476. [CrossRef]

83. Zhang, Y.; Cao, H.; Zhao, P.; Wei, X.; Shi, M. Vegetation Restoration Alters Fungal Community Composition and Functional Groups in a Desert Ecosystem. Front. Environ. Sci. 2021, 9, 589068. [CrossRef]

84. Ai, C.; Zhang, S.; Zhang, X.; Guo, D.; Zhou, W.; Huang, S. Distinct responses of soil bacterial and fungal communities to changes in fertilization regime and crop rotation. Geodera 2018, 319, 156-166. [CrossRef]

85. Wang, J.; Yuan, Y.; Zhang, M.; Dai, X.; He, H.; Li, H.; Li, Y. Impact of degradation and restoration on soil fungi and extracellular enzyme activity in alpine rangelands on the Tibetan Plateau. Arch. Agron. Soil Sci. 2021, 14, 1917-1929. [CrossRef] 